\title{
Implications of next-generation sequencing for the systematics and evolution of the terrestrial orchid genus Epipactis, with particular reference to the British Isles
}

\author{
Richard M. Bateman ${ }^{1}$ (D)
}

Summary. Recent application of next-generation sequencing technology to Eurasian taxa of the primitive epidendroid orchid clade Epipactis section Epipactis has further advanced our knowledge of what has become a model system for studying the origins of numerous autogamous taxa from within arguably only one allogamous ancestral species, E. helleborine s.s. Current understanding of evolutionary pattern, species re-circumscription and speciation process within Epipactis is critically reviewed, emphasising the relevance of recent research based on next-generation sequencing and aiming to better understand taxa native to the British Isles. Conclusions include recognition that (1) the majority of named taxa currently widely viewed as species do not pass rigorous tests of species status, (2) two of the six unequivocal species native to Britain extend further east in Eurasia than was previously supposed, and none is endemic, (3) all scientifically defensible species of Epipactis have high frequencies of self-pollination (although autogamy is significantly less frequent in the ancestral species E. helleborine than in any of the remaining species derived from it), and (4) fully understanding the speciation process (including substantial increases in autogamy) will require us to further investigate not only pollinator behaviour and the diverse factors determining gynostemium morphology but also the equally diverse factors (including mycorrhizal specificity) likely to influence the invasion of novel, challenging habitat types.

Key Words. allogamy, ancestor-descendant relationships, autogamy, evolutionary radiation, fluctuating asymmetry, geitonogamy, speciation; species circumscription; species concept.

\section{Introduction}

The orchid family encompasses more than its fair share of 'critical groups' that present serious challenges to those of us attempting to better circumscribe species and to anyone attempting field identifications within those groups. And if the species themselves are at best difficult to identify and at worst biologically indefensible, what hope exists of confidently identifying putative hybrids between them? In southern Europe, it is bee orchids of the genus Ophrys that most commonly furrow the brows of field botanists. But within the British Isles, the orchid groups that strike most fear into the heart are Dactylorhiza (especially the tetraploid majalis aggregate), its sister genus Gymnadenia, and the helleborine aggregate within Epipactis (i.e. section Epipactis, which contains all British species other than the distinctive, phylogenetically distant E. palustris: taxonomic authors are given in Table 1). It is perhaps no coincidence that only these three 'critical' genera each include one or two species currently thought to be endemic to the British Isles, but that all four putative endemic orchids remain taxonomically contentious and difficult to identify, irrespective of whether classical morphology or DNA data are being employed as identification tools.

The latest weapons in the systematist's armoury are a set of DNA-based techniques, collectively termed next-generation sequencing (NGS: this and other technical terms associated with evolutionary genetics are defined in Box 1), that generate vast amounts of genetic data from each plant analysed, encompassing a significant proportion of their genomes (e.g. Harrison \& Kidner 2011; Olson et al. 2016). At present, these approaches remain technically challenging in terms of data generation, filtration and analysis, at least for a non-expert such as myself. Having already applied one such technique, RAD-seq (Box 1), to Ophrys (Bateman et al. 2018) and Dactylorhiza (Brandrud et al. 2019), my colleagues and I then

Accepted for publication 1 August 2019. Published online 29 April 2020

1 Jodrell Laboratory, Royal Botanic Gardens, Kew, Richmond, Surrey, TW9 3DS, UK. e-mail: r.bateman@kew.org 
Table 1. Revised classification of British and Irish Epipactis taxa to subspecies level. The downgraded status of 'sancta' is provisional, pending future whole-genome sequencing and morphometric comparison. Asterisked taxa contain one or more varietal epithets still in occasional use (excluding the chlorophyll-deficient individuals that occur rarely in all species and are better viewed as formae).

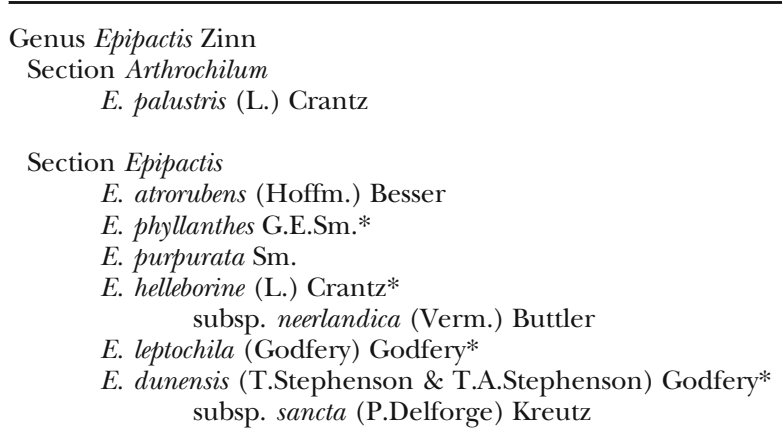

turned our attention to Epipactis (Sramkó et al. 2019). In doing so we sought to improve the poor phylogenetic resolution achieved by previous studies that were able to target only small numbers of genes (e.g. Bateman et al. 2005; Tranchida-Lombardo et al. 2011). Although this latest, NGS-based molecular study of Epipactis was funded in Hungary, and hence emphasised plants from eastern Europe, its results nonetheless have several intriguing implications for our understanding of the genus in Britain and Ireland, where much previous research has been performed on the genus. It is fortunate that our native populations of Epipactis encompass a representative cross-section of the overall morphological and molecular variation found in the genus (Fig. 1).

\section{What has NGS ever done for us?}

Sramkó et al. (2019) analysed NGS data for 108 plants of 29 named taxa, 27 of which belonged to the helleborine group. Geographical sampling extended from Portugal to Russia, and from Denmark to Greece. Detailed analysis and careful interpretation based on an explicit set of taxonomic rules formulated by Bateman (e.g. 2009) resolved the 27 names into just 11 genuine species, plus a further three well-founded subspecies. Determining whether the remaining formal names represented in the analysis are most appropriately viewed as subspecies or, more likely, varieties or formae requires further, more precisely targeted research generating morphometric as well as molecular data. Moreover, a further 38 named taxa recognised by Delforge (2016) within section Epipactis remain to be investigated using NGS approaches.

Despite the key historical role played by British botanists in Epipactis taxonomy, only nine of the 108 samples analysed by Sramkó et al. (2019) were derived from Britain: two plants of E. dunensis from the Lancashire coast plus one from inland Cumbria (var. tynensis), single plants of E. phyllanthes from the Lancashire coast and an Oxfordshire beechwood, more beechwood plants in the form of E. leptochila from its locus classicus in Surrey plus a controversial population in Buckinghamshire attributed by some observers to 'E. neglecta', and a pair of samples of E. helleborine s.l. from Kenfig dunes in Glamorgan - one sample from Salix repens scrub purporting to be subsp. neerlandica and the other from back-dune woods purporting to be subsp. helleborine. Sadly, no room was found in the sample set for British material of E. atrorubens, E. purpurata or the controversial UK endemic from Lindisfarne, 'E. sancta', despite the fact that both E. purpurata and E. 'sancta' have their type localities in England. We can nonetheless make some useful observations on their current status in the light of improved understanding of other closely related taxa.

Viewed from a purely methodological perspective, the British plants offer a valuable indication of the impressive accuracy of RAD-seq via Illumina sequencing - the nextgeneration sequencing techniques used by Sramkó et al. to generate their data and resulting trees (e.g. Fig. 2). The two samples of Epipactis dunensis collected c. $5 \mathrm{~km}$ apart in the Lancashire dunes are perceived as virtually genetically identical. More remarkably, so are the two samples of E. phyllanthes, despite the fact that the Lancashire dunes sample was collected $280 \mathrm{~km}$ distant from its Oxfordshire counterpart. Less happily, the Welsh duneland sample of E. helleborine subsp. neerlandica is also strikingly molecularly similar to the sample originally attributed to E. helleborine subsp. helleborine that was collected in back-dune woodland just $500 \mathrm{~m}$ distant. Only the two UK samples of E. leptochila deviate from this pattern of close similarity between British pairs; that from the Surrey locus classicus of this species lies (appropriately) at the phylogenetic centre of the leptochila clade in Fig. 2, whereas the plant from the more controversial Buckinghamshire population is placed as sister to the remaining samples of E. leptochila s.l. - an intriguing observation that is discussed at greater length below.

\section{A chequered taxonomic history}

Viewed with the benefit of hindsight, the taxonomic history of the Epipactis helleborine aggregate reads rather like a masked ball, many of the protagonists catching occasional glimpses of truth but failing to discern the bigger picture. Authors who followed the traditional taxonomic pathway by addressing locally taxonomic problems that actually required a global solution reliably reached contrasting solutions that led to ever greater nomenclatural confusion.

The UK has consistently played a leading role in progressing the taxonomy of the Epipactis helleborine aggregate per se. Admittedly, E. helleborine itself was first described - presumably from Swedish material - by Linnaeus (1753) and E. atrorubens from German material 
Box 1. Glossary of evolutionary terms used in this text (in some cases followed in parentheses by more precise definitions specific to the present study of Epipactis).

allogamy: The fusion of two gametes derived from two distinct individuals (here, the transfer by insects of pollen from one Epipactis stem/clone to the stigma of another)

autogamy: The fusion of two gametes derived from a single individual (here, the transfer of pollen within or between flowers of one Epipactis stem/clone)

bootstrap support: A crude but widely used estimate of the strength of particular nodes in a phylogeny that relies on repeatedly constructing sets of trees from subsets of the original data-set and determining the relative frequencies with which particular relationships survive these statistical perturbations

cryptogamy: A specialised form of autogamy in which gametes are transferred within the same reproductive unit without ever being exposed to the external environment (here, the transfer of pollen between fertile stamen and stigma within a single bud that never opens)

evolutionary radiation: A large surplus in the rate of natality over the rate of mortality for species and/or character states within a specified clade [= monophyletic group] through a specified time interval [Bateman 1999, p. 441] (here, simplified to the less rigorous concept of several species apparently originating from within a single ancestral species through a comparatively short period of geological time)

fluctuating asymmetry: Small random deviations from perfect symmetry evident in bilaterally paired structures or within a single bilaterally symmetrical structure (here, a comparison of the dimensions of paired lateral sepals and lateral petals)

geitonogamy: A specialised form of autogamy in which gametes are transferred between different reproductive units of the same stem/clone (here, the transfer of pollen between flowers within the same inflorescence or between different inflorescences of a single genetic clone)

Hardy-Weinberg equilibrium: Core [but simplistic] theory of population genetics stating that in the absence of any evolutionary influences the frequency of particular copies of genes within a population will remain constant across generations

inbreeding coefficient $(\boldsymbol{F})$ : The estimated probability that an individual inherited two homologous [comparable] copies of a particular gene from a single ancestor

next-generation sequencing (= high-throughput sequencing): An umbrella term for several analytical methods that allow comparatively rapid sequencing of large numbers of nucleic acids simultaneously for numerous individuals [e.g. Illumina, 454, ion torrent]

monophyletic: A group of taxa or individual organisms encompassing a single hypothesised ancestor and all of its descendants (here, an exclusive group of analysed samples that in a reconstructed evolutionary tree are subtended by a single shared node)

paraphyletic: A group of taxa or individual organisms encompassing a single hypothesised ancestor and some but not all of its descendants (here, a non-exclusive group of analysed samples that in a reconstructed evolutionary tree are subtended by a single shared node)

phylogeny: A diagrammatic hypothesis inferring the evolutionary relationships of a specified group of organisms (here, a rooted dichotomising tree based on RAD-seq data)

polyphyletic: A 'non-group' of taxa or individual organisms encompassing two or more hypothesised ancestors (here, a non-exclusive group of analysed samples that in a reconstructed evolutionary tree are subtended by two or more nodes)

RAD-seq (= restriction site-associated DNA sequencing): A sequencing strategy that uses restriction sites to characterise a significant proportion of an entire genome to identify myriad single nucleotide polymorphisms [SNPs] in next-generation sequence data

reproductive isolation: A degree of evolutionary independence achieved through one or more of a wide spectrum of mechanisms capable of substantially reducing or prohibiting gene flow between co-occurring organisms

speciation: Origin of a novel species from within at least one ancestral species via one or more of a wide spectrum of evolutionary mechanisms

species circumscription: The search for discontinuities in intrinsic properties that distinguish a set of populations and their constituent individuals from all others and imply that they collectively constitute an independent evolutionary lineage (here, primarily reflected in comparatively long internal branches within the RAD-seq-based phylogeny)

species concept: One or more specified fundamental principles considered essential when circumscribing species [many, often highly contradictory, concepts have been proposed in the literature]

by Hoffmann (1804: a taxon quickly elevated to species level by Besser 1809), but the remaining four (or five) species of the aggregate currently viewed as occurring in the British Isles (Fig. 1) have all been based on British types. The next species to be segregated from E. helleborine was $E$. purpurata, described as a full species from an atypically anthocyanin-less Worcestershire plant by J. E. Smith (1828). However, even as late as the early 20th Century, both E. purpurata and E. atrorubens were lumped into E. helleborine in the then dominant British Flora of Bentham \& Hooker (1920). Another Smith (G. E. Smith 1852) then used Sussex material as the basis for describing E. phyllanthes, but with such brevity and in a publication so obscure that his observations were overlooked for several decades (they were even neglected by Godfery [1933] in his otherwise excellent monograph of British orchids).
The collective failure of botanists to correctly circumscribe $E$. phyllanthes festered at the centre of many years of taxonomic confusion. Several taxa occurring in the British Isles were subsequently established that actually belong within E. phyllanthes; even Summerhayes' (1951) landmark orchid book discussed not one but two 'species', E. 'vectensis' and E. 'pendula'. These and other named taxa were subsequently sensibly reduced in rank to varieties of E. phyllanthes by Young (1952a, b; see also Young 1962b; Lewis 2017), enabling Summerhayes (1968) to correct his error in the second edition of his book.

Responsibility for the discovery and subsequent advocacy of Epipactis leptochila fell to Godfery (1919, 1920, 1921, 1933), based primarily on a morphologically extreme population that still persists today in Surrey (Fig. 1E). It eventually led to a burgeoning of 

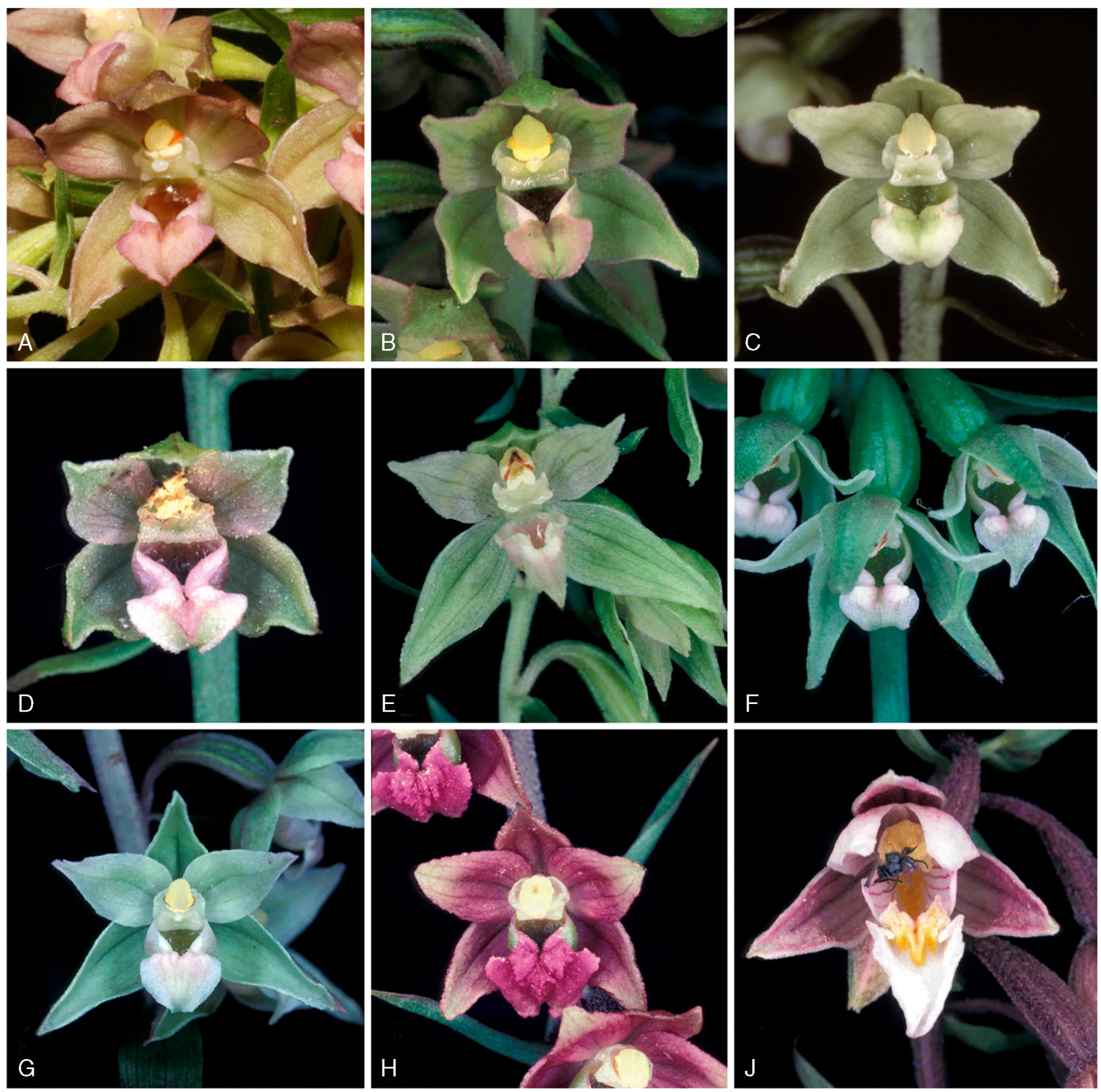

Fig. 1. Flowers of all widely accepted species of the genus Epipactis native to the British Isles, reproduced at a consistent scale. A C E. helleborine helleborine; D E. dunensis (locus classicus); E E. leptochila (locus classicus); $\mathbf{F}$ E. phyllanthes; $\mathbf{G}$ E. purpurata; $\mathbf{H}$ E. atrorubens (all section Epipactis); J E. palustris (section Arthrochilum). Horizontal dimension of each image =C. $18 \mathrm{~mm}$. PHOTOS: A - E, G - J R. M. BATEMAN; F D. M. T. ETTLINGER.

supposed species in Continental Europe that are actually attributable to E. leptochila (Sramkó et al. 2019). The establishment of E. dunensis was more complex. Wheldon \& Travis (1913) first drew attention to dunensis, which was formally described by T. \& T. A. Stephenson (1918) from Lancashire dune material as a forma of E. helleborine, but three years later was elevated by them to a variety of E. leptochila (Stephenson \& Stephenson 1921) - an eyebrowraising taxonomic status that nonetheless was supported as recently as the 1990s by Allen et al. (1993).
Inevitably, dunensis was soon raised to species level by Godfery (1926), who had recently first described E. leptochila and was therefore well-equipped to identify its morphological distinction from E. dunensis. However, all of these treatments were complicated by widespread confusion caused by the ongoing failure of authors to recognise the existence of $E$. phyllanthes as a cohesive and separate species. Northumbrian populations of E. 'tynensis' (Fig. 3A, B), a further taxon now clearly best treated infraspecifically within E. dunensis, were initially attributed to E. leptochila by 


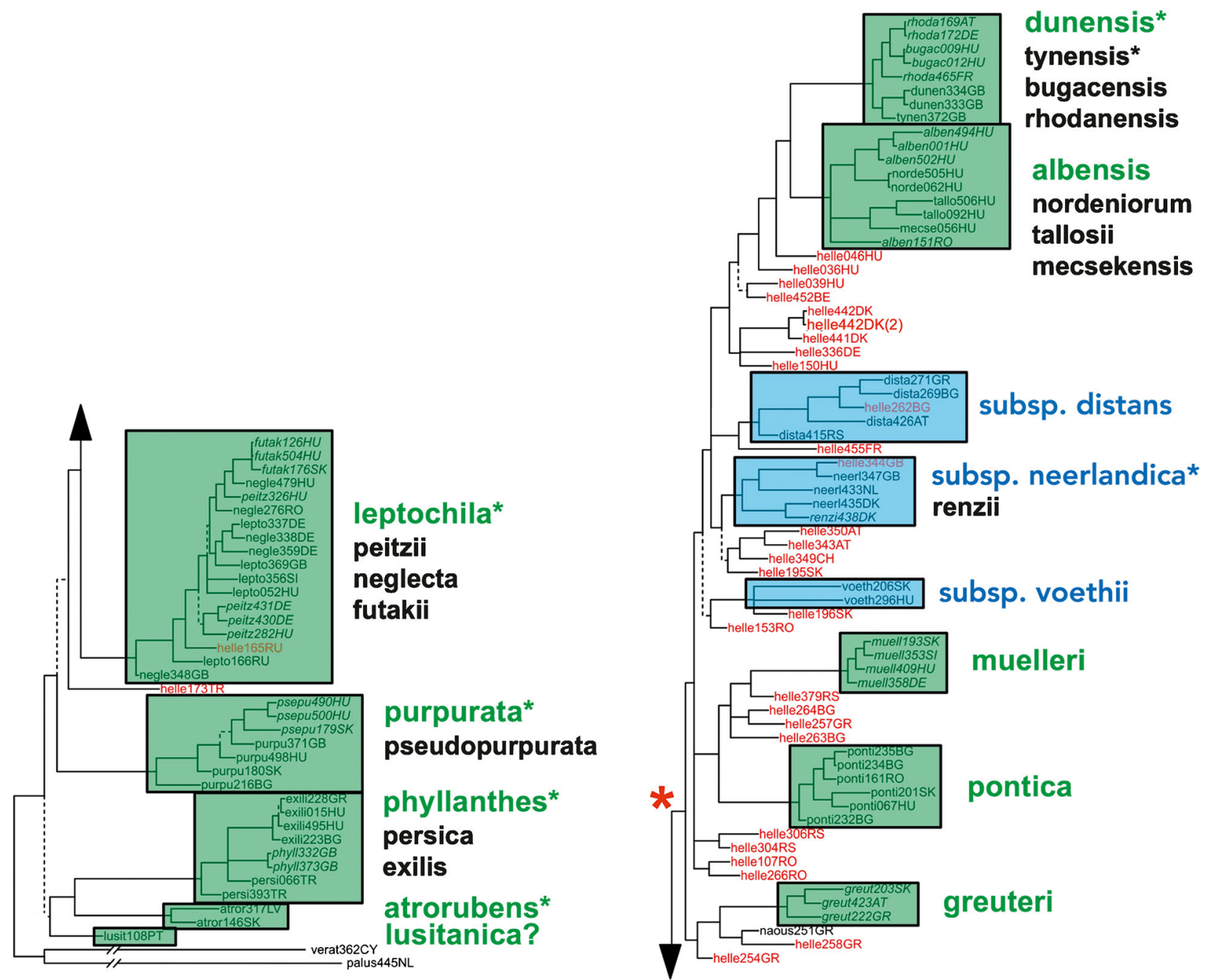

Fig. 2. Maximum Likelihood phylogram depicting the evolutionary relationship of the studied Epipactis plants based on RAD-seq data analysed using RAxML. Samples of the ancestral species E. helleborine subsp. helleborine are highlighted in red. Recircumscribed species are placed in green boxes and subspecies in blue boxes; taxa occurring in the British Isles are asterisked. Collapsed branches attracted approximate likelihood ratio test support values of less than $80 \%$ and dashed branches achieved only $80-90 \%$ support. The red asterisk marks the only branch to have received meaningful support from the previous study of targeted nuclear and plastid genes by Bateman et al. (2005). Source country codes: AT, Austria; BE, Belgium; BG, Bulgaria; CH, Switzerland; CY, Cyprus; DE, Germany; DK, Denmark; FR, France; GB, Britain; GR, Greece; HU, Hungary; LV, Latvia; NL, Netherlands; PT, Portugal; RO, Romania; RS, Russia; SK, Slovakia; TR, Turkey. Modified after Fig. 3A of Sramkó et al. (2019).

Richards \& Swan (1976). These Tyneside populations were later clearly shown to be referable to $E$. dunensis by the molecular studies of Hollingsworth et al. (2006; reviewed by Harrap 2009) and latterly Sramkó et al. (2019). A taxonomic transfer to E. dunensis was formalised at subspecies rank by Kreutz (2007), though Delforge (2016) subsequently argued that tynensis should be demoted to a mere variety. A further duneland taxon, E. helleborine subsp. neerlandica, also occurs in the British Isles (Fig. 3C, D); its significance is highlighted below in a separate section.

Even the most recently described British Epipactis, E. sancta, rapidly became a taxonomic football. The epithet has been applied only to a single tenuous population endemic to dunes on the small island of Lindisfarne, located just off the northeast coast of England (Fig. 4). It was introduced to the taxonomic community by Delforge (2000) as a variety of the supposedly wholly continental putative species $E$. peitzii - a taxon since rejected as a species by Sramkó et al. (2019) and shown to be referable not to $E$. dunensis but rather to E. leptochila. Sancta was raised to a full species by Delforge in Delforge \& Gévaudan (2002), but later placed (more credibly when viewed in the light of recent studies) as a subspecies of $E$. dunensis by Kreutz (2007). Among British authors, the species status of sancta was tentatively supported by Squirrell et al. (2002), Hollingsworth et al. (2006) and Bateman (2006); subse- 

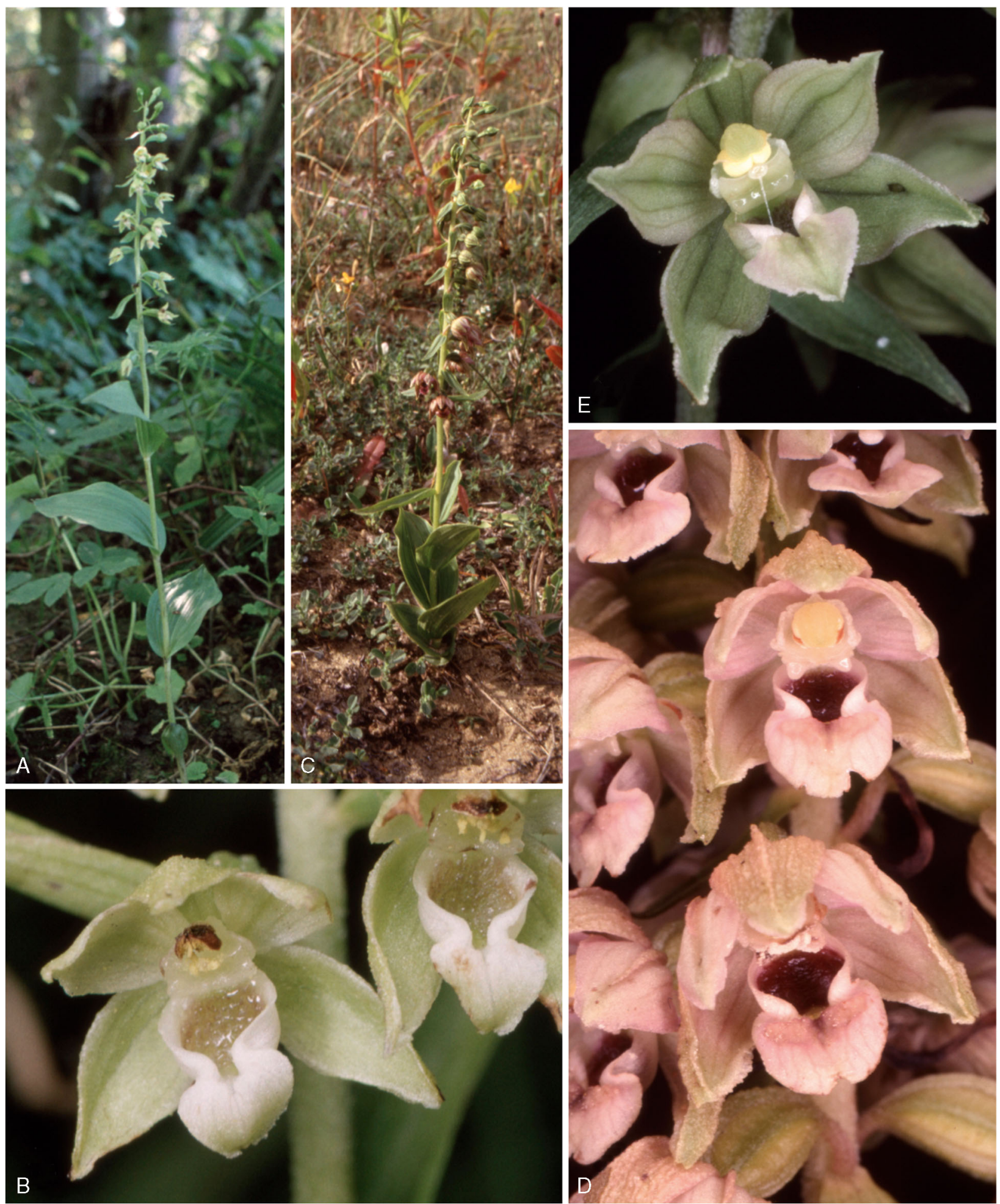

Fig. 3. A, B Epipactis dunensis var. tynensis; C, D E. helleborine subsp. neerlandica; E E. helleborine subsp. helleborine var. youngiana, a taxon previously demoted from species level to varietal level based primarily on its possession of a molecular signature indistinguishable from that of var. helleborine. PHOTOS: A - C D. M. T. ETTLINGER; D, E R. M. BATEMAN.

quently also by Harrap \& Harrap (2009) and Stace (2010). Supporting arguments rested primarily on the undesirably narrow grounds that sancta combined molecular characteristics of E. dunensis (as inferred from nuclear-encoded allozymes) and E. leptochila (as inferred from the plastid region trnL-F). Given perennial con- 

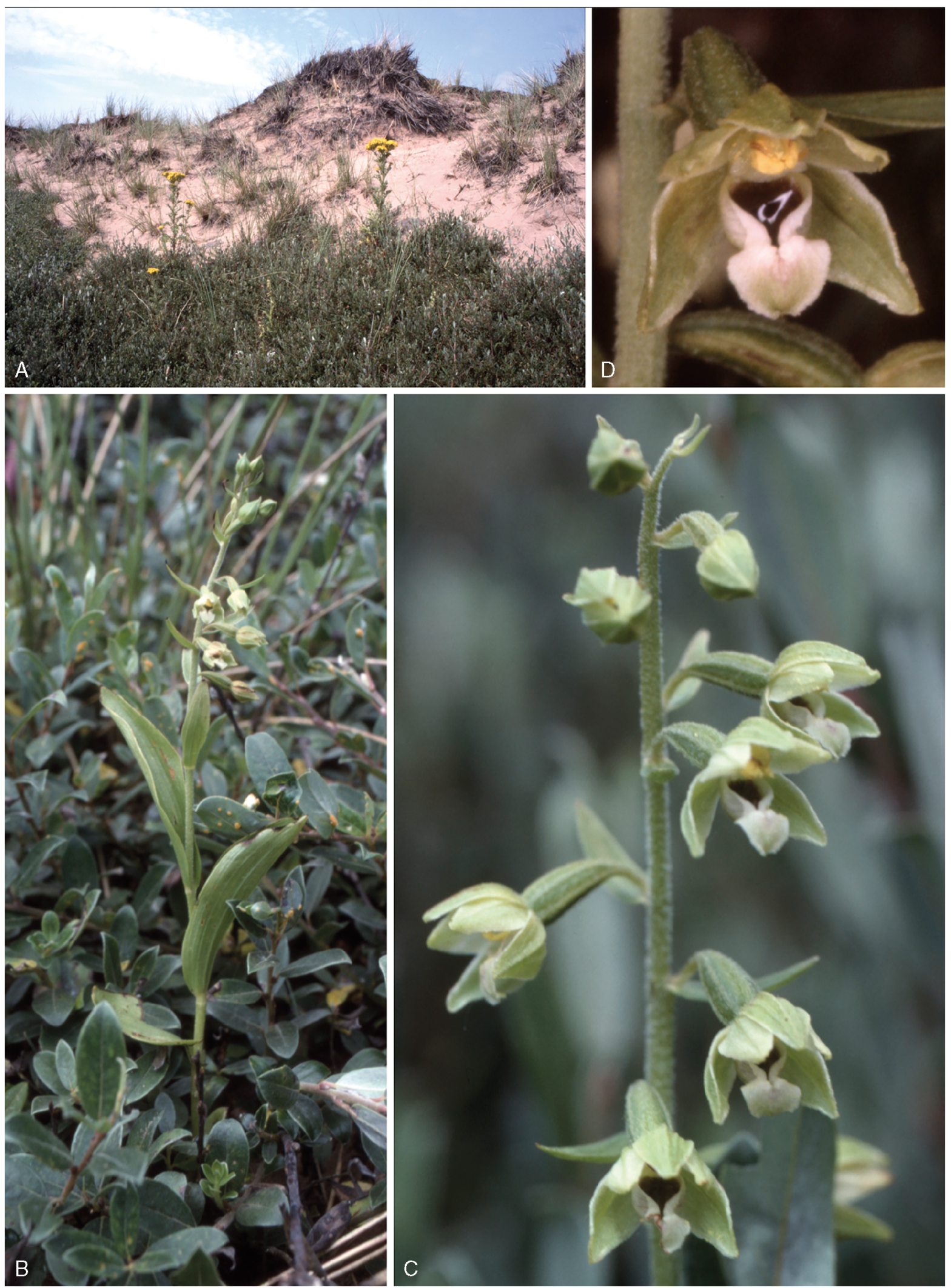

Fig. 4. Epipactis 'sancta', a supposed species probably attributable to E. dunensis s.l.; this is one of only four putative species of orchids potentially endemic to the British Isles and therefore of considerable conservation interest. A duneland habitat on Lindisfarne showing two plants in the centre foreground; B typical whole plant; C inflorescence; D close-up image of individual flower. PHOTOS: A - C R. M. BATEMAN; D D. M. T. ETTLINGER. 
cerns regarding the most appropriate status for sancta (e.g. Richards \& Squirrell 2009), the absence of this taxon from the more data-rich analysis of Sramkó et al. (2019) is regrettable; sadly, suitable material was unavailable when the analyses were performed.

Understandably, Sramkó et al. (2019) saw no ongoing reason to further explore 'Epipactis youngiana' (Fig. 3E). This supposed local endemic was first described from a disused lead mine in Northumbria by Richards \& Porter (1982), prompting tentative additional reports of the newly described taxon from several other regions of the British Isles (e.g. Ettlinger 1997, 1998) and briefly becoming the subject of a UK Biodiversity Action Plan (Anonymous 2007). The credibility of this taxon as anything more than a variety or forma of E. helleborine was seriously wounded by an allozyme study performed by Harris \& Abbott (1997) before being unequivocally killed as a putative species by Hollingsworth et al. (2006), on the solid grounds that plants of var. youngiana always occur among, and freely exchange genes with, substantial numbers of more typical E. helleborine plants. A varietal status for youngiana was formally established by Kreutz (2004) and was subsequently widely accepted (Lang 2004; Bateman 2006; Hollingsworth et al. 2006; Stace 2010; Delforge 2016).

Lastly, there has in recent years been considerable informal discussion regarding a rather dispersed and sporadic 'metapopulation' of Epipactis leptochila centred on the Chilterns escarpment east of Princes Risborough, Buckinghamshire. At least three explanations have been offered for its apparently somewhat deviant morphology of certain subpopulations; either attribution to the Continental taxa E. muelleri or E. 'neglecta' (the latter shown to be synonymous with E. leptochila by Sramkó et al.: Fig. 2) or gene exchange with nearby plants of E. helleborine. Unfortunately, the data gathered by Sramkó et al. (2019) are ambiguous with regard to the gene exchange hypothesis; a coalescence analysis presented as a 'heat map' and designed to identify gene exchange between close relatives proved negative, but on the other hand, the analysed plant from Risborough yielded an $F$ measure of inbreeding (see discussion below) that was consistent with the comparatively allogamous (cross-fertilising) E. helleborine but radically different from that typical of the more strongly autogamous (self-fertilising) E. leptochila. Thus, the jury remains undecided regarding the identity of this particular population.

\section{Kenfig Dunes as a case-study}

A remarkable amount of attention has been paid to the members of the Epipactis helleborine aggregate occurring in the extensive dune systems of South Wales, particularly that near Kenfig in Glamorgan. This dune system has at various times been accused of harbouring four named taxa in the aggregate: E. 'cambrensis', E. 'neerlandica', E. 'youngiana' and E. helleborine s.s. (cf. Ettlinger 1997, 1998; Lewis 2003; Lang 2004; Lewis \& Spencer 2005; Delforge 2006; Harrap \& Harrap 2009; Lewis et al. 2009; Clark 2011; Jacquemyn et al. 2018; Kapteyn den Boumeester 2018b). Epipactis 'cambrensis' of Thomas (1950) falls well within the unusually broad spectrum of varietal-level morphological variation shown by populations of E. phyllanthes (Lewis \& Spencer 2005; Lewis et al. 2009) and so need detain us no longer. However, the plants awarded the epithets youngiana and especially neerlandica present a more interesting challenge (Fig. 3).

The first written evidence of the apparent presence of what they both regarded as Epipactis helleborine var. neerlandica in Kenfig is a 1952 letter from British Epipactis expert Donald Young to Dutch orchid taxonomist Pieter Vermeulen (Kapteyn den Boumeester 2018b). It is a taxon that had been first described from the Netherlands by Vermeulen (1949) as a variety of E. helleborine elevated to a subspecies by Buttler (1986) and finally with painful inevitability, to full species by Delforge $e t$ al. (1991). But it was Ettlinger (1997, 1998) who explicitly drew the attention of British orchid enthusiasts to the possible occurrence of neerlandica at Kenfig. Lewis (2003) and Lewis \& Spencer (2005) confirmed the presence of plants at Kenfig that resembled the Dutch coastal taxon neerlandica but also noted the presence of occasional plants in scrubby back-dune woodland that appeared to be more typical of E. helleborine helleborine. Also present was a further morphotype that they considered to more closely resemble the supposed British endemic youngiana of Richards \& Porter (1982). Lewis (2003) credibly speculated that youngiana was a taxon that originated in multiple regions due to heavy metal pollution of soils. Following extensive international consultation, Lewis et al. (2009) confirmed the presence at Kenfig of neerlandica but decided that this taxon should also include the plants previously attributed by them to youngiana.

The number and nature of the morphological characters that supposedly distinguish neerlandica from helleborine s.s. have been much debated and the majority found to be seriously compromised (cf. Vermeulen 1958; Buttler 1986; Kapteyn den Boumeester 1989, 2018a, b; Van den Bussche 2004; Kreutz 2005; Kuiper et al. 2009; Lewis et al. 2009). After monitoring through several years the morphology of Kenfig plants of both duneland neerlandica and woodland helleborine s.s., Clarke (2011) advanced an elegant set of qualitative observations that led him to conclude that the neerlandica morphotype was merely an environmentally induced ecotype (termed by him an 'ecad') of helleborine s.s. and predicted that they would prove to lack genetic distinction. Based on field observations made in 2009, Kapteyn den Boumeester (2018b) also reached the conclusion that the dune- 
land and woodland plants represented the same taxon, but instead argued that "the plants growing among the trees were not subsp. helleborine but were instead subsp. neerlandica, adapted to the shade."

I must confess that, prior to data collection, I viewed with considerable scepticism the idea that the Welsh plants attributed to neerlandica would prove to be comparable with those in its core distribution along the North Sea coastline of Belgium, the Netherlands and Denmark (reviewed by Ehlers et al. 2002; Jacquemyn et al. 2018). It seemed highly unlikely that a taxon with a very recent origin, most likely emerging in these North Sea dune systems (Jacquemyn et al. 2018), would have a radically disjunct distribution that included South Wales. However, that is the most likely interpretation that can be placed on the RAD-seq results obtained by Sramkó et al. (2019).

Their NGS tree reveals a single cluster of five relevant samples, four attributed to neerlandica and one to helleborine s.s. (Fig. 2). This shows that the Kenfig plants attributed to neerlandica and helleborine s.s. are strongly similar genetically, certainly sufficiently similar to be viewed as representing the same subspecies (cf. Figs 1A - C, 3C, D). Their closest relative is a sample of neerlandica from the Netherlands coast, and the British and Dutch samples have as their closest relative samples from Danish dune systems of neerlandica and its supposedly strictly self-pollinating segregate, the Danish endemic neerlandica renzii (the two samples also proving very similar to each other). These relationships suggest that neerlandica most likely originated recently and in Denmark, later spreading westwards to the Netherlands and eventually to South Wales. Certainly, these results seriously challenge my initial scepticism regarding the disjunct distribution of neerlandica; indeed, they suggest that neerlandica should be sought in the intervening extensive dune systems of Norfolk and Lincolnshire.

Unfortunately, other than the supposed sample of Epipactis helleborine s.s. from the Kenfig back-dune woodland, Sramkó et al. did not include any samples of $E$. helleborine s.s. from the British Isles, so we cannot be absolutely certain that British populations would yield genetic profiles comparable with those of the French, Belgian and Danish populations that were sampled. However, on present evidence it seems probable that Clark (2011) and Kapteyn den Boumeester (2018b) were correct to synonymise at species level the Kenfig neerlandica (including the already debunked 'youngiana') with E. helleborine s.s. Indeed, Kapteyn den Boumeester (2018b) gains the laurels by predicting that (a) the whole Kenfig population should all be attributed to a single taxon, (b) that the relevant taxon is indeed neerlandica, and (c) that neerlandica is a valid subspecies. Certainly, these dune populations evidently merit more than the varietal status collectively awarded to them by several colleagues (including Stace 2010); they are rather a stabilised and possibly expanding western European dune ecotype best viewed as E. helleborine subsp. neerlandica (Jacquemyn et al. 2018; Sramkó et al. 2019).

Thus, after about 70 years of debate, three 'species' once again become one, albeit a species (Epipactis helleborine s.l.) containing a subspecies that might eventually evolve into a bona fide species (neerlandica) and a variety that most likely will be subsumed back into the mainstream (youngiana).

\section{Revised taxonomic circumscriptions}

Given recent observations, most notably the newly published NGS data of Sramkó et al. (2019), we can now usefully review our current understanding of the circumscription of all of the genuine species (and some infraspecific taxa) occurring in the British Isles (Fig. 2), and produce an updated infrageneric classification at the levels of section, species and subspecies (Table 1).

With regard to British national floras, we can now see that the species-level circumscriptions published by Clapham (1962), Clapham et al. (1987) and Stace (2010) were remarkably accurate; only Stace's (2010) admittedly lukewarm recognition of Epipactis sancta as a local endemic species deviates from my current views, and was probably prompted by my own arguably premature statements (Bateman 2006). Admittedly, Stace (1991) had earlier treated E. dunensis as a mere variety of E. leptochila, while Sell \& Murrell (1996) treated both E. leptochila and E. dunensis as varieties of E. muelleri. In contrast, the analysis of Sramkó et al. (2019) reinforces previous morphological and molecular evidence that E. leptochila and E. dunensis are relatively distantly related to each other (contra the rather quixotic rearguard action fought by Richards \& Squirrell 2009) and that the equally evolutionarily distant E. muelleri is exclusively Continental. Moreover, Sell \& Murrell followed Stace (1991), Allen et al. (1993) and Ettlinger (1997, 1998) in recognising E. helleborine var. youngiana (Fig. 3E) as a full species, presumably because their traditional taxonomic treatment was published immediately prior to publication of the first molecular study of this taxon (Harris \& Abbott 1997). These and other fundamental weaknesses in the formal treatment of British and Irish orchids by Sell \& Murrell (1996) ably illustrates that further understanding of our flora is unlikely to be achieved through herbarium-based floras.

From a purely nomenclatural perspective, the species-level synonymies identified by Sramkó et al. (2019) of supposedly Continental (especially eastern European) species with their British counterparts reliably benefit our native species; the relevant taxa 
were formally described (often from British material) prior to any synonymous taxa being established in Continental Europe based on non-British types. Thus, it falls to Continental systematists to decide whether to accept the evidence presented by Sramkó et al., demonstrating the scientifically demonstrated requirement for synonymisation according to the law of nomenclatural priority. Regrettably, nomenclatural issues all too often become the tail that wags the proverbial taxonomic dog. Certainly, the chequered taxonomic history of European Epipactis makes abundantly clear the desirability of pursuing a geographically and taxonomically broad, monographic approach to taxonomy, rather than establishing formally named taxa on a piecemeal, ad hoc basis over a considerable period of time. Such an approach simply generates confusion that can require centuries to remedy.

Viewed from a British perspective, the Sramkó et al. study makes clear that no bona fide Epipactis species is endemic to the British Isles. Even the most westerly species, E. dunensis and E. leptochila, extend as far east as Hungary (cf. Molnár 2011), and the majority of the valid species stretch at least as far as the eastern boundary of Europe. Unfortunately, it is not presently feasible to assess species distributions - certainly not beyond the British Isles - because traditional taxonomy has yet to catch up with current systematic knowledge. Based on past experience, it may never do so.

Certainly, the number of formal names proposed for Epipactis taxa still continues its steady expansion, most recently affecting Russia (Fateryga \& Fateryga 2018). For example, a supposed new autogamous species endemic to a narrow region of Russia east of the Black Sea, E. 'euxina', was recently segregated from E. 'persica' by Fateryga et al. (2018) as a result of traditional taxonomic comparison with E. 'persica', E. 'exilis', E. 'fageticolca' and E. leptochila. It seems extremely unlikely that E. 'euxina' is a bona fide species, given that the DNA data of Sramkó et al. (2019) show that the cases for species status are equally poor for persica, exilis and most likely fageticola; all of these supposed taxa are actually attributable to E. phyllanthes. In other words, the taxonomic over-splitting of E. phyllanthes that was attempted in Britain during the early part of the 20th century and was later universally rejected (even before molecular data became available) is now being attempted elsewhere in Europe during the early part of the 21st century. Such taxonomic over-splitting is further epitomised by another recent paper (Ardelean et al. 2018) that reports the discovery in Romania of four additional 'species' of Epipactis, three of which lack the necessary biological credentials of a bona fide species; the Sramkó et al. tree (Fig. 2) shows that E. 'nordeniorum' and E. 'tallosii' belong within E. albensis, and E. 'exilis' within
E. phyllanthes. Clearly, it is time to step back and seriously review current, genuinely scientific knowledge of the genus.

\section{Species concept(s) employed}

We should perhaps pause at this point to consider which rules and criteria were employed by Sramkó et al. (2019) in order to convert the relationships of sampled plants (summarised here as Fig. 2) into species and subspecies. I had published a set of guidelines on several previous occasions (e.g. Bateman 2009), but tackling section Epipactis required the addition of codicils to those rules. "Recognise only monophyletic groups" became "Recognise monophyletic groups except where a paraphyletic ancestral species remains clearly identifiable", while it proved necessary to amend "Preferentially divide the tree at branches that are relatively robust (and usually comparatively long within the context of the tree in question)" to take account of the longer branches caused by increased retention of mutations and/or fixation of alleles in plants that are predominantly autogamous.

The requirement for monophyly recognises inclusive groups where there is no need to qualify any group by making exceptions (for example, in Fig. 2, if we were to decide to recognise Epipactis 'pseudopurpurata', it would be necessary to circumscribe E. purpurata as "all plants in the E. purpurata group except those attributed to E. pseudopurpurata"). But in Fig. 2, recognising 13 monophyletic groups as 10 species and three subspecies has left us with a "paraphyletic rump" of several clusters of samples of E. helleborine s.s. - the ancestral species that apparently gave rise to all the remaining taxa. This is exactly what one would expect to see in a molecular phylogeny in genuine cases of ancestor-descendant relationships; I suspect that the reason such phylogenetic patterns are rarely encountered is because that relationship rapidly becomes masked by further mutations and extinction of intermediate lineages, such that for nonrecent speciation events ancestor and descendant species are more likely to be represented as sisters. Thus, in this particular case, recognising 13 monophyletic species and subspecies in Fig. 2 obliges us to accept one nonmonophyletic species, as the only other option would be to divide E. helleborine into several supposed species that would not be distinguishable on morphological grounds.

In this context, it is important to note in passing that some hard-core phylogeneticists and population geneticists deny the applicability to genetic data of the concept of ancestor-descendant relationships. Part of the inspiration for such a puritanical position can perhaps be traced back to the famous pronouncement of Greek philosopher Heraclitus (c. 570 B.C.) that roughly translates as "No man ever steps in the same 
river twice, for it's not the same river and he's not the same man." In this case, allele frequencies observed in the putative ancestor and descendant species today would differ from those pertaining at the time when genuine Epipactis species first became (largely) genetically independent from each other. This statement may be true for neutral genetic markers effectively acting as mutational Geiger counters, but for those markers that provide ongoing cohesion of the two species and allow their morphological discrimination, it cannot be true because those discriminating differences would not then persist. Species circumscription is, at its heart, a search for morphological discontinuities that have genetic underpinnings that in turn provide a high degree of reproductive isolation (Bateman 2001, 2012, 2016). In this particular case, the emergence of several bona fide species from within E. helleborine, thus rendering E. helleborine profoundly paraphyletic, is taken here as offering strong if circumstantial evidence for its role as a (very) common ancestor. Although this statement constitutes an admission that $E$. helleborine as circumscribed here has not remained fully coalesced from a genetic perspective, I find acknowledging this fact a small price to pay for then being able to explore a far more comprehensive evolutionary scenario for section Epipactis.

Returning to the core thread of using evolutionary trees to circumscribe taxa, branch length becomes exceedingly important for differentiating between monophyletic groups that should be treated as species, subspecies and groups worthy of varietal rank at best. Monophyly alone is an inadequate basis for circumscribing taxa. Species are expected to be subtended by a comparatively long branch, subspecies to be subtended by a shorter one (although in the present case, subspecies that are presumed autogams are also identified by longer terminal branches subtending individual plants (Fig. 2). Congruence with traditional taxonomy is also considered when dividing up a tree, although congruence with morphological phylogenies or morphometric ordinations would offer more powerful and informative comparisons. Sadly, such analyses are not currently available across section Epipactis.

The application of monophyly as a criterion for species circumscription is more controversial (and certainly more problematic) than applying it to circumscribe supraspecific taxa. Clearly, it alone cannot circumscribe species; a family (human, not taxonomic) of parents and children is likely to be resolved as monophyletic if they are genetically tested and the resulting data are imported into mathematical algorithms designed to generate dichotomous trees, but that property alone does not make the family a distinct species. The length (usually broadly proportional to the statistical robustness) of branches in trees is an essential companion to monophyly.
So what does this simple set of rules (perhaps better described as guidelines) and underlying principles mean in terms of species concepts applied? Although some ancillary information employed in the taxonomic decision-making of Sramkó et al. (2019) was derived from other studies presenting traditional morphological descriptions, together with crossing experiments and ecological observations broadly linked to so-called biological species concepts, the main thrust of their arguments was based on their own genetic data. The data were explored within a conceptual framework that is lineage-based and largely corresponds with both the cohesion species concept of Templeton (1989) and the evolutionary species concept of Wiley \& Mayden (2000: 73): "an evolutionary species is an entity composed of organisms that maintains its identity from other such entities through time and over space and that has its own independent evolutionary fate and historical tendencies."

\section{Evolutionary implications}

\section{The questions}

The Epipactis helleborine complex (Figs 1, 3, 4) has become a textbook case of plant evolution. Initial interest focused on the realisation that flowers of the majority of the species segregated from E. helleborine s.l. had various morphological features that collectively rendered them more likely to experience (or, to put it another way, less able to prevent) self-pollination (e.g. Young 1948, 1952a, b, 1962a, b; Proctor \& Yeo 1973; Richards 1982, 1986a, b; Robatsch 1995; Proctor et al. 1996; Claessens et al. 1998; Pedersen \& Ehlers 2000; Squirrell et al. 2002; Hollingsworth et al. 2006; Claessens \& Kleynen 2011).

Observers therefore began to ask the question of whether this phenomenon followed a gradual trend or underwent a more radical evolutionary transition? And if a genuine transition, was it responsible for the speciation event or simply a downstream consequence of it? As the theoretical background to plant reproductive biology became more sophisticated, later authors raised additional questions, such as whether dominant or even complete autogamy represented an evolutionary dead-end or whether such species could alternatively have given rise to further species (e.g. Takebayashi \& Morrell 2001; Igic \& Busch 2013; Wright et al. 2013; Barrett et al. 2014), either themselves also dominantly autogamous or possibly even reverting to a considerably greater frequency of crosspollination? If the transition to autogamy is indeed an evolutionary dead end then all of the species that appear dominantly autogamous must by definition have evolved independently. If this is the case, then which species acted as the ancestor of which autogamous species? 
At this point, more systematics-oriented questions come into play. Could the centuries of taxonomic confusion between Epipactis helleborine and the remaining taxa in the helleborine complex actually reflect an evolutionary cause, specifically multiple origins of new species in different geographic locations across Eurasia from within a single ancestor, namely E. helleborine helleborine? If so, approximately when and where did each speciation event occur? And if most or all of these speciation events do indeed prove to have occurred over a short time-scale from within a single geographically widespread species (i.e. E. helleborine s.s.), can we legitimately refer to the E. helleborine complex as having undergone a genuine evolutionary radiation, using the criteria established by Bateman (1999; definition in Box 1)? Last, but by no means least, if these speciation events occurred recently when measured against a geological time-scale, can we justifiably refer to that radiation as still being active? Such bold assertions have rarely been made for specific taxonomic groups within the plant kingdom, as they are extremely difficult to demonstrate with any great conviction.

\section{What the $F$ ?}

Their NGS matrix allowed Sramkó et al. (2019) to address each of these questions. Ironically, I believe that the first question - the nature of the evolutionary transition leading to speciation - remains the most difficult to answer with confidence. Sramkó et al. chose to seek evidence of allogamy versus autogamy in their NGS using two contrasting statistical approaches. $F$ statistics offer a direct estimate of inbreeding (strictly, of heterozygosity relative to Hardy-Weinberg equilibrium) in each plant, which should provide a good approximation of the level of self-fertilisation that has occurred in the lineage averaged backwards through numerous generations. The co-ancestry approach is also designed to expose examples of recent gene exchange between comparatively closely related plants. No obvious examples of recent hybridisation were exposed by Sramkó et al.'s (2019) co-ancestry analysis. In contrast, the $F$ statistics revealed six individuals of diverse taxonomic attribution that possessed low $F$ values comparable with those of Epipactis helleborine. Two of these were plants identified upon collection as being respectively E. lusitanica (a taxon morphologically similar to, and arguably synonymous with, E. helleborine) and E. 'naousaensis', a reputedly rare and poorly understood local endemic from Greece that proved genetically indistinguishable from a plant of E. helleborine collected nearby. The four remaining samples showing low $F$ values were all single individuals of taxa supposed to be either facultative or obligate autogams: an E. phyllanthes exilis from Bulgaria, an E. phyllanthes persica from Turkey, an E. helleborine distans from Russia, and an E. leptochila from a Buckinghamshire population that is considered by some visiting orchid enthusiasts to be of hybrid origin. I find it difficult to explain these anomalously low $F$ values, so obviously atypical of all other individuals assigned to the same taxon, in any way other than through hybridisation occurring within the last few generations of the 'family history' of each of these plants.

Sramkó et al. (2019) chose to analyse their F statistics primarily in the context of four prior categories: obligate allogams, facultative allogams, facultative autogams and obligate autogams. Attribution of each plant to one of the four categories was achieved largely on reproductive biology as inferred from features of the gynostemium, a few anecdotal observations of its morphology commonly being generalised across each named taxon. No direct quantitative examination was made of the gynostemia of individual study plants in vivo at the time of sample collection for genetic analysis. In the absence of such data, it seems to me more logical to re-analyse the $F$ statistics on the basis of membership of monophyletic groups as re-circumscribed within the rooted molecular tree published by Sramkó et al. (Fig. 2). It also seems reasonable to omit from the calculations the six anomalous plants discussed above. The results of the revised analysis are presented here as Fig. 5. It should be emphasised that sample sizes per re-circumscribed species are small $(2-27$, mean 7.7$)$ and that error bars

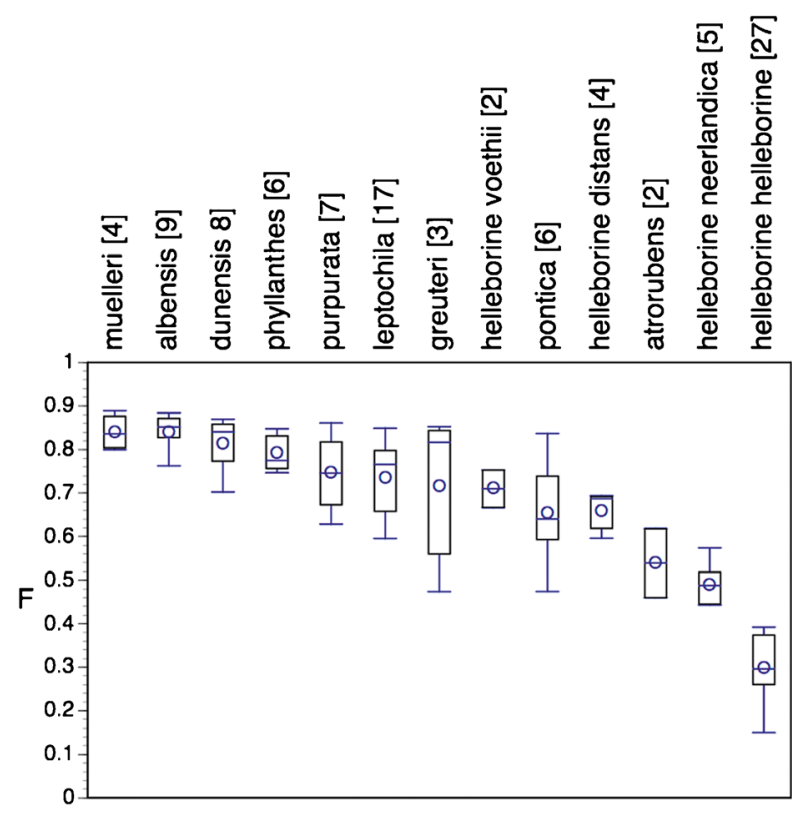

Fig. 5. Box plot showing means and sample standard deviations of the inbreeding coefficient $(F)$ per recircumscribed taxon within the Epipactis helleborine group, based on figures calculated by Sramkó et al. (2019) and produced for the present study using Deltagraph v.7.1.2. The blue circles denote mean values. The black box is terminated by the 25th and 75th percentiles; the horizontal blue line within the box denotes the 50th percentile, and the extended blue 'whiskers' mark the 10th and 90th percentiles. Sample sizes are given adjacent to the taxon names. 
for the less well-sampled among the clades are therefore comparatively large.

Three reputedly dominantly cleistogamous taxa, shown by Sramkó et al. to be best viewed as subspecies or varieties, yielded remarkably consistent mean $F$ values: +0.83 for Epipactis purpurata pseudopurpurata, +0.82 for E. phyllanthes exilis and +0.80 for E. leptochila futakii. Given that the gynostemium of cleistogamous plants is (at least in theory) inaccessible to potential pollinators, it seems logical to assume that these are the Epipactis plants that are least likely to experience cross-pollination. If so, they provide us with a useful indication of $F$ values that are likely to represent nearobligate autogamy. In fact, it is clear from Fig. 5 that these mean values are matched by the largely noncleistogamous species E. muelleri, E. albensis, E. dunensis and E. phyllanthes s.l., and only slightly exceed values obtained for E. purpurata s.l., E. leptochila s.l. and possibly E. greuteri (which here has a mean value that is distorted by one deviant sample). Values for $E$. pontica (comparatively variable), E. helleborine voethii and E. helleborine distans are somewhat lower (c. +0.65$)$, as are those for the two outgroups selected from within Epipactis section Arthrochilum (E. palustris and $E$. veratrifolia). Values for $E$. atrorubens and E. helleborine neerlandica approximate +0.5 , the supposedly obligately autogamous var. renzii of neerlandica actually achieving a far from obligate $F$ value of just +0.45 . Only at this point in the gradation of $F$ values do we encounter a genuine jump in values; the species ancestral to this plexus, E. helleborine helleborine, has a substantially lower mean of c. $+0.3 \pm 0.1$. Sramkó et al. (2019, fig. 3) argued that three of the four transitions between their prior groups were statistically significant; only the supposed transition separating their bins for facultative versus obligate autogamy failed a Mann-Whitney test. But re-assessing the data on the basis of re-circumscribed species, as in the present Fig. 5 , gives a substantially different result. It serves primarily to distinguish the ancestral plexus of E. helleborine helleborine (and perhaps also lusitanica) from the remaining, evolutionarily derived species and subspecies, which do not fall comfortably into a series of convenient reproductive bins. All taxa other than E. helleborine helleborine apparently grade from frequent to near-complete autogamy.

At this point, it is important to note that the theoretical range of the $F$ statistic is not from zero to plus one, as might be inferred from Fig. 5, but rather from minus one (theoretical maximum outbreeding) to plus one (theoretical maximum inbreeding). Several complicating factors mean that it would be oversimplistic to interpret the results summarised in Fig. 5 as a strictly arithmetic scale and thus view a mean of zero as a perfect balance between inbreeding and outbreeding. Nonetheless, it is clear from these figures that even Epipactis helleborine s.s. is actually far removed from an obligate allogam. Sramkó et al. (2019) listed several factors that could, either individually or collectively, push all Epipactis species toward frequent autogamy. They included the much-discussed structural variation in morphological features competent to increase cohesion of pollen tetrads within pollinia or to preclude pollen massulae from reaching the stigma of the same flower. It is important to remember that any genetic control of such features is inevitably overprinted with ecophenotypic phenomena such as rapid desiccation of the viscidia that attach pollinaria to visiting insects.

However, on the basis of field observations in particular, I suspect that the relatively high frequency of autogamy is caused primarily by geitonogamy - the tendency for insects to visit multiple flowers on the same inflorescence, thereby transferring pollen between genetically identical flowers (e.g. Kropf \& Renner 2008). This phenomenon is especially prevalent in species of flowering plants that offer a substantial nectar reward, as do all Epipactis, because the reward extends the residency of an insect on the inflorescence (e.g. Claessens \& Kleynen 2016). Insect residency is also increased if inflorescences bear large numbers of large flowers, as do all Epipactis taxa, and if rhizomatous growth allows a single plant to generate multiple inflorescences - a particularly strong trend in members of the section Arthrochilum outgroup but also frequently observed in most members of section Epipactis. It therefore seems likely to me that, even in E. helleborine s.s., only a minority of successful pollination events are cross-pollinations. And in the experimentally demonstrated weakness of any intrinsic sterility barriers (Tałalaj \& Brzosko 2008; Brys \& Jacquemyn 2016), self-pollination is highly likely to lead to self-fertilisation. Given that experimental crossing experiments yielded very similar results for E. helleborine s.s. and E. atrorubens, the contrast in their mean $F$ values evident in Fig. 5 is unlikely to reflect any intrinsic factors and hence is more likely to reflect a higher average frequency of geitonogamy in E. atrorubens. These are readily testable hypotheses.

\section{Another F: fluctuating asymmetry}

Further evidence of routine autogamy (albeit circumstantial evidence) can be gained from the morphology of the affected organisms. Theory states that protracted autogamy and the resulting decrease in population-level genetic diversity should lead to increased frequencies of developmental anomalies (e.g. Graham et al. 2010; Klingenberg 2010). And certainly, in the case of the Epipactis helleborine complex, the tendency in several species for the labellum to become simplified and more sepal-like (e.g. Young 1952b; Bateman \& Rudall 2006) supports such an inference. The simplest way to explore the phenotypic effects of 
prolonged autogamy is to study the amount of deviation from perfect bilateral symmetry in specific organs - a phenomenon termed fluctuating asymmetry. I therefore mounted and measured the widths (and, in the case of the lateral tepals, lengths) of all six tepals of flowers in order to measure any deviation between left and right tepals (lateral tepals) or left and right half-tepals (median tepals). The study was based on two flowers removed from each of ten plants of E. helleborine (Fig. 1A) and ten plants of E. leptochila (Fig. 1E), both species being sampled at the Surrey locus classicus of E. leptochila in August 2016.

Positive correlation of asymmetry values proved to be poor between the pairs of flowers taken from the same plant, indicating that the resulting data were noisy and probably incorporated a degree of experimental error. This was particularly true when attempting to define a midline in order to measure half-widths of the median tepals; these data were therefore discarded from further analysis. Averaged out over all four lateral tepal measurements for both flowers per plant from all ten plants, the degree of asymmetry was estimated at $3.5 \pm$ $1.8 \%$ for Epipactis helleborine and $4.0 \pm 1.9 \%$ for E. leptochila (set against a background of c. $1 \%$ measuring error for both species). Thus, although mean right-left asymmetry was, as expected, assessed as being greater in the more strongly autogamous E. leptochila, the quantitative difference between the two species was slight and not statistically significant. It would appear that although functional constraints over the floral phenotypes of the more strongly autogamous Epipactis species may have diminished, the genetic consequences have not (yet) become sufficiently entrenched to adversely affect developmental controls on their floral symmetry.

\section{The (provisional) answers}

We now return to the rhetorical questions posed at the beginning of this 'Evolutionary Implications' section. Based on current evidence, the re-circumscribed species within the Epipactis helleborine group are best simply apportioned among two reproductive categories rather than four: moderately autogamous s.l., mainly reflecting geitonogamy (primarily E. helleborine helleborine), and strongly to almost obligately autogamous (the remainder), reflecting genetically and/or environmentally induced self-pollination of individual flowers, supplemented with geitonogamy in all autogams other than the few genuinely cleistogamous populations. Provided that populations currently attributed to E. helleborine in Iberia (e.g. Tyteca \& Dufrene 1994), Russia (e.g. Efimov 2004) and Asia Minor can in the future be more clearly confirmed as correctly identified - an outcome that is by no means certain — the NGS tree of Sramkó et al. (2019) implies that all of the remaining, more strongly autogamous species (highlighted in green on Fig. 2) and at least three valid subspecies (highlighted in blue) arose independently from within this single ancestral plexus.

Given this comparatively rare example of the recent origin of several taxa from within just one ancestral taxon, via one or more processes that have generated species in some cases but only subspecies in others, it is difficult to view the Epipactis helleborine aggregate as having undergone anything other than an evolutionary radiation as defined in Box 1 (albeit lacking the desirable comparative yardstick of a fossil record of Epipactis - necessary if we were to establish the background rates of speciation and extinction required by the conservative definition proposed by Bateman 1999). Moreover, that radiation would appear to remain active today. This conclusion highlights the value of the helleborine aggregate as a model group for the study of plant evolution.

The most obvious possible exception to the general statement that all of the more recent species were derived from Epipactis helleborine s.s. is the highly autogamous sister pairing of the predominantly western European E. dunensis and the predominantly central European, later-flowering E. albensis (Fig. 2). Their relationship as mutually monophyletic sisters means that one species probably (though not definitely) gave rise to the other, although the tree does not help us to identify which of the two species is the more likely to be ancestral to the other. However, this relationship does usefully imply that, although evolutionary trajectories favouring increased autogamy do generally result in species that are evolutionary dead ends, this popular assumption may actually constitute an evolutionary guideline rather than an unbreakable rule.

Each of the genuine Epipactis species that occurs in Britain and Ireland (Table 1) has as its sister an individual of E. helleborine from central or eastern Europe. This is not entirely surprising, given that western European samples were in a minority among the samples analysed. Nonetheless, the results are consistent with all of the species occurring in Britain and Ireland having originated in eastern Europe or possibly, in the case of E. phyllanthes, even in Asia Minor. Only the western European E. helleborine subsp. distans appears to have actually originated in western Europe, given that its sister sample of E. helleborine subsp. helleborine was collected in France. Even the western European E. helleborine subsp. neerlandica, a taxon characteristic of the western seaboard of Europe, has as its sister-group four individuals of E. helleborine subsp. helleborine sampled in Switzerland, Austria and Slovakia (Fig. 2). It appears that Epipactis, a genus of the orchid subfamily Epidendroideae, shares with other Eurasian orchid genera assigned to subfamily Orchidoideae a pattern of successive speciation events occurring 
during an overall westward migration of the lineage.

It is clear that speciation in the Epipactis helleborine complex is reliably positively correlated with increased inbreeding frequency, which interestingly is routinely manifested as an increased rate of retained mutations or allele fixation and thus generates longer subtending branches on molecular trees (Fig. 2). However, at this point I feel it essential to deploy the age-old maxim of science that correlation does not necessarily reveal causation. It is noteworthy that the ancestral species E. helleborine is even more widespread and frequent than are its descendant species, presumably because they reliably show narrower ecological tolerances. Having said that, some of the derived species do possess the ability to invade habitats shunned by E. helleborine helleborine. Examples include on the one hand E. dunensis and E. helleborine neerlandica occupying poorly stabilised dune 'soils' exposed to intense sunshine but on the other hand E. leptochila surviving in darkened calcareous beechwoods devoid of other ground vegetation. Indeed, in the woodlands of the Chiltern Hills and North Downs of southern England it has proven possible to use the respective distributions of E. helleborine and E. leptochila versus that of E. purpurata to map the boundary between thin calcareous chalk soils and the thicker mildly acid clay-rich soils developed in the overlying chalk residue that is informally termed clay-with-flints.

These observations lead me to wonder whether our long-term obsession with the reproductive biology of these plants has to some degree blinded us to potentially important events occurring at the opposite end of the plant from any pollinator visitation, specifically the roots. Ample evidence has accumulated to show that these species rely heavily on mycorrhizae for carbon nutrition (Bidartondo et al. 2004; Jacquemyn et al. 2016; Schiebold et al. 2017), and a study of fungi on the roots of Epipactis microphylla suggested a comparatively high degree of mycorrhizal specificity (Selosse et al. 2004). Is it possible that transitions in mycorrhizal communities could have permitted occupation of these more austere, insectdeficient habitats, and that the increased frequency of autogamy in these species was a later consequence, rather than a cause, of speciation?

Certainly, there is an intriguing symmetry in the relationship between the moderately autogamous Epipactis helleborine s.s. and the remaining, more strongly autogamous taxa within the helleborine group. Epipactis helleborine s.s. is undeniably the more widespread and locally frequent among the species, but its more strongly autogamous derivatives are also more geographically widespread than conventional wisdom suggested; I suspect that, collectively, they sequester as much biomass as their shared parental species, suggesting the existence of some form of emergent trade-off between the number of novel lineages generated and degree of ecological success. In summary, it would be overly simplistic to view from first principles these strongly autogamous taxa as being ecologically inferior to their more allogamous brethren.

As a postscript to this section of the paper, I would emphasise that section Epipactis offers excellent opportunities to explore experimentally feedback loops between evolutionary lineage and environment. In terms of pollination biology, both of the main drivers toward autogamy - gynostemium phenotypes permitting self-pollination of a single flower and geitonogamy permitting cross-pollination of genetically identical flowers on a single ramet - are vulnerable to ecophenotypy. A comparatively desiccating environment soon renders the viscidium dysfunctional and the pollinium friable, thereby encouraging self-pollination, and even partial or more rarely complete cleistogamy also tends to occur more frequently in dry soils. Meanwhile, factors such as exposure to wind and degree of shade inevitably affect the frequencies (both relative and absolute) of visits from various species of potential pollinating insects and the behaviour that they typically exhibit once they have elected to alight on an inflorescence. Lastly, I note that these environmental influences would impact more strongly, and have a more rapid and direct effect on evolution, if it can be demonstrated that they can lead to heritable change through epigenetic mechanisms (e.g. Paun et al. 2010).

\section{UK conservation status of section Epipactis taxa requires radical revision}

In the case of section Epipactis, the comparatively recent Red List for England (Stroh et al. 2014) simply echoes comments and decisions made a decade earlier in the Red List for Great Britain (Cheffings et al. 2005). This treats section Epipactis under the rather prejudicial banner of "apomicts and other complex groups", arguing that "Epipactis phyllanthes, E. leptochila, E. sancta, E. dunensis and E. youngiana form a problematic complex of self-pollinated plants in which species limits are the subject of [?ongoing] research. Speciation is considered to be still taking place. Conservation for this group may be best to be "process-based'." (Cheffings et al. 2005: 6).

Understandably, youngiana was placed on the 'Parking List' of rejected taxa, presumably on the grounds that it "shows incontrovertible evidence that it should be placed at a lower rank than subspecies" (Cheffings et al. 2005: 98), although the main evidence justifying that statement was not published until the following year (Hollingsworth et al. 2006). Remarkably, all of the remaining species of section Epipactis, 
including the widespread E. helleborine, appear on the Red Lists. Most are categorised as Least Concern, although E. leptochila and E. dunensis are listed as Data Deficient on the spurious grounds that data for these two species are confounded by the fact that they were formerly recorded as conspecific. In fact, the period of taxonomically confused mapping was brief and the mutually exclusive distributions of the two species have actually long been well documented. In contrast, the taxon for which data deficiency is genuinely most problematic, E. 'sancta', is categorised as Endangered, primarily on the grounds of an endemic population size estimated in 2013 at just 70 plants and despite currently being seriously 'data deficient'. 'Sancta' was also labelled as an "international responsibility", as was E. phyllanthes. This status is defined as requiring us to be "sure that the UK holds more than $25 \%$ of European populations." In the case of E. phyllanthes, this designation is unlikely to survive Sramkó et al.'s (2019) demonstration that E. phyllanthes is conspecific with E. exilis and E. persica (and probably with a further four exclusively mainland Eurasian Epipactis 'species' recognised by Delforge 2016) (Fig. 2).

The statements made in the Red Lists that selfpollination is frequent and speciation is still taking place within section Epipactis are amply justified by the results of recent research. However, arguing that all putative species of section Epipactis should appear on the Red List because they as a group are being actively researched seems somewhat perverse. Is knowledge of taxonomic groups that are not being actively researched truly more concrete? Indeed, what proportion of the British and Irish flora has ever been the subject of more than superficial scientific research? Moreover, the concept that cases of active speciation require "process-based" conservation strategies is simply unsustainable. Fig. 2 and Table 1 clearly illustrate the substantial number of species and subspecies that have evolved in recent times from within E. helleborine. In order to preserve the full evolutionary potential of section Epipactis it would indeed be necessary to conserve the species that is demonstrably the cradle of multiple dominantly self-fertilising lineages, namely E. helleborine, but this species is widespread, locally common and even occasionally accused of being invasive (reviewed by Squirrell et al. 2001). Conserving the whole of section Epipactis would hardly be a practical prospect when set against the many other factors and species that should be considered when making conservation decisions. Given that these speciation (and subspeciation) events are likely to represent the few successes among myriad failed attempts, how can we possibly predict which populations will eventually lead to speciation and so prioritise them? In the increasingly man-made world in which we now live, we have little choice but to leave evolution in general, and incipient speciation in particular, to take care of itself. 'Process-based conservation' is literally for the birds.

\section{Ongoing challenges}

Despite recent progress, the systematic challenges posed by the Epipactis helleborine group are far from settled. History has taught me that the predilection shown by the European orchid community for piecemeal formal description of new taxa in the absence of meaningful scientific data will continue unabated, along with subsequent games of snakes-and-ladders (or perhaps tit-for-tat?) as formally named taxa migrate between taxonomic ranks with little or no underlying justification, either theoretical or empirical (reviewed by Bateman 2012, 2016, 2018). Indeed, my own previous, tentative advocacy of E. 'sancta' as a full species based primarily on a single small difference in the plastid $t r n L-F$ gene (Bateman 2006) may eventually prove to fall within this particular category of sin.

One obvious weakness of even present knowledge is that resource limitations meant that Sramkó et al. analysed only 27 of the 65 putative species recognised by Delforge (2016), although I suspect that the putative species carefully selected for their NGS analyses may eventually prove to have encompassed all of the bona fide species other than Epipactis microphylla. It is already clear that the majority of the 'species' within the helleborine group that are currently recognised in European orchid monographs fail the crucial test summarised by Bateman (2009) of monophyly plus adequate levels of genetic divergence (it should probably be noted once again at this point that Fig. 2 makes clear that E. helleborine s.s. is itself clearly strongly paraphyletic rather than monophyletic, as a direct consequence of its impressive ability to generate other, more strongly autogamous, species). However, greatly increased population sampling is desirable to strengthen these early attempts to recircumscribe species and infraspecific taxa using population-level NGS data (Bateman 2012, 2016).

But by far the greater problem in progressing species circumscription in the genus Epipactis is the consistent unwillingness of researchers (not least, of myself and my colleagues) to commit the extensive periods of time necessary to gather large, geographically and taxonomically broad morphometric data-sets. These are an essential pre-requisite for the multivariate analyses needed to integrate morphological studies with the increasingly sophisticated molecular investigations. Compared with other taxonomically problematic genera such as Dactylorhiza and Gymnadenia, Epipactis has been greatly under-researched morphologically. Richards (1982) scored just ten metric characters in British populations of several Epipactis species, primarily to compare levels of morphological variation rather than to circumscribe taxa. The studies of E. helleborine in Sweden by Ehlers et al. (2002) and of E. leptochila in the 
Alps by Gévaudan (1999) adopted an approach broadly similar to that of Richards. Tyteca \& Dufrene (1994) studied a wider range of morphological characters in populations of several members of the E. helleborine group located along the Atlantic seaboard of Continental Europe. However, their study was also somewhat weakened by confining their matrix to characters that were both continuously variable (metric and meristic sensu Bateman 2001) and macroscopic, omitting less readily coded characters such as flower colours or cell shape and size (perhaps for this reason, the credible pairing of E. atrorubens and E. microphylla was placed improbably close to $E$. helleborine in the similarity-based comparative tree of Tyteca \& Dufrene 1994). A similar range of characters was studied by Jacquemyn et al. (2018) when comparing two populations each of E. helleborine helleborine and E. helleborine neerlandica in Belgium. Forty years of experience have taught me that at least 40 morphometric characters need to be measured in order to give an adequate overall assessment of the morphology of an orchid (or indeed of any other vascular plant); in practice, this means that scalar and presence/absence characters must be scored in addition to metric/meristic measurements (Bateman 2001). And Epipactis plants are sufficiently morphologically complex to permit recognition of considerably more than 40 characters.

Within the British Isles, several questions regarding Epipactis remain to be answered with the necessary confidence. The most obvious of these is the need to conduct NGS and morphometric studies to determine the most appropriate status for E. 'sancta' (Fig. 4). At present, several pieces of circumstantial evidence encourage me to believe that sancta is most appropriately treated as a subspecies of E. dunensis; if this ultimately proved to be the case it would return this population full circle to the species assignment originally determined by Young (1962a). Firstly, although sancta is only now being subject to rigorous morphometric analysis, and usable morphometric data have not yet been gathered for comparable taxa, the morphology of sancta appears on present inadequate evidence to differ only very subtly from that of E. dunensis (primarily the absence from the pedicel of pink anthocyanin pigments - a characteristic unlikely to have any functional, and thus selective, value). Secondly, the limited DNA data currently available suggest that sancta more closely resembles $E$. dunensis in nuclear genes but E. leptochila in plastid genes (although very few genes of either category have been sequenced thus far). Of relevance here is the fact that subsequent NGS techniques have suggested that, for closely related orchid taxa, nuclear genes are on average more accurate than plastid genes (Bateman et al., unpublished). Thirdly, the NGS study of Sramkó et al. (2019) effectively challenged the credibility of species status awarded by others to any of the supposed local endemic species that they sampled across Europe; all 11 of the bona fide species that survived species-level re-circumscription are geographically widespread. This outcome makes the rare, extremely local endemic sancta (Fig. 4) appear much more anomalous than previously.

The NGS-prompted recognition that some Epipactis species extend much further east in Europe than was previously widely believed also encourages further consideration of the converse question of whether one or more of the species currently thought to be confined to mainland Europe may actually be present in the British Isles. For example, E. muelleri - long recognised as occurring immediately beyond the English Channel in the Low Countries - has long been sought in the UK but has yet to be convincingly found here (cf. Young 1962a; Delforge 1995; Lang 2004). Of course, current limitations on morphological knowledge mean that even if E. muelleri does occur in the British Isles it would be challenging to record with confidence, thus making yet another strong case for developing an NGS-based portable device suitable for field-based sequencing of DNA (e.g. Bateman 2016). In the case of other taxa, notably E. helleborine subsp. neerlandica (Fig. 3C, D), improved knowledge means that determining the distribution of the subspecies within the British Isles is now the primary issue, rather than simply confirming its presence. Surprisingly, the work of Sramkó et al. (2019) suggests that neerlandica might have a single evolutionary origin, most probably in the Dutch dunes. If so, neerlandica subsequently spread to South Wales, rather than arising independently there as I previously believed. The single-origin hypothesis requires a migratory jump westward that is exceptionally longdistance, even by the standards of the dust-seedequipped orchid family. Also, post-glacial sea level fluctuations mean that neerlandica most likely arrived in the South Wales dunes within the last 3,000 years. Like E. muelleri, neerlandica also would be most readily identified using a portable device capable of DNAbased analysis. The apparent absence from Ireland of E. leptochila (admittedly, there have been occasional rumours that it occurs in Co. Antrim: Curtis \& Thompson 2009) and especially of E. dunensis also appears surprising, given the availability of apparently suitable habitats; further, carefully targeted exploration in Ireland appears desirable.

Primary hybrids have long been sporadically reported in Britain between Epipactis helleborine and each of E. atrorubens, E. purpurata and E. leptochila (Godfery 1933; Stace 2010; Richards in Stace et al. 2015). I suspect that, through the last four decades, I have during fieldwork seen rare examples of each of these three combinations, but again genetic data are necessary for confident identification. Despite the fact that both species are dominantly autogamous, it seems 
likely that E. dunensis and E. phyllanthes also hybridise at least rarely; at some localities they occur together in large numbers, most notably along the Lancashire dunes. Lastly, hybrids between E. leptochila and E. dunensis were listed as occurring in Britain by Lang (2004), despite the mutually exclusive distributions in Britain of the supposed parents. Overall, there is a need to study gene flow within multi-species populations of Epipactis, if only to further explore the apparent incongruence between the inbreeding coefficients ( $F$ statistics) and co-ancestry heat map presented by Sramkó et al. (2019, their figs. 3B and 5).

Much progress has been made in recent years in better understanding speciation patterns and processes within section Epipactis. If we continue to operate on the long-held assumption that gynostemium morphology has at least some influence on the likelihood of self-pollination, it is essential that we determine the relative contributions of genetic, epigenetic and ecophenotypic (i.e. environmental) factors in determining that morphology. We also need much more ambitious pollinator observations - studies that are designed specifically to track the course of pollen flow among flowers rather than simply identifying the pollen vectors to species level (while accepting that making sufficient numbers of observations will not be easy for the species with the lowest frequencies of cross-pollination). And we need to pay far more attention to 'housekeeping' aspects of Epipactis plants, such as the effectiveness of their photosynthetic machinery under contrasting light levels, the nutrient-absorbing ability of their rootstocks, and the identity and nature of the mycorrhizae that both inhabit the roots and assist germination of the dustseeds (Jacquemyn et al. 2016). Determining the sequence in which key events occur during their evolution - change of floral morphology, increased autogamy, altered habitat preference - will be crucial to finally unravelling speciation process(es) operating in these provocative yet intriguing plants.

\section{Acknowledgements}

I especially thank Gábor Sramkó for funding and overseeing the Hungarian parent project that prompted this more individualistic (and nationalistic) review. Gábor, Ovidiu Paun and Marie Brandrud generated both the RAD-seq tree here reproduced with modification as Fig. 2 and the $F$ statistics used by me to generate Fig. 5. I also thank Peter Hollingsworth for long ago persuading me of the full evolutionary significance of this fascinating group of plants, and the late Derek Turner Ettlinger for (also long ago) bequeathing to me his ever-useful reserve set of European orchid slides. Paula Rudall and Ian Denholm kindly critically appraised this text, followed by two generous (but sadly anonymous) reviewers.
Open Access This article is licensed under a Creative Commons Attribution 4.0 International License, which permits use, sharing, adaptation, distribution and reproduction in any medium or format, as long as you give appropriate credit to the original author(s) and the source, provide a link to the Creative Commons licence, and indicate if changes were made. The images or other third party material in this article are included in the article's Creative Commons licence, unless indicated otherwise in a credit line to the material. If material is not included in the article's Creative Commons licence and your intended use is not permitted by statutory regulation or exceeds the permitted use, you will need to obtain permission directly from the copyright holder. To view a copy of this licence, visit http://creativecommons.org/ licenses/by/4.0/.

\section{References}

Allen, B., Woods, P. \& Clarke, S. (1993). Wild orchids of Scotland. HMSO, Edinburgh.

Anonymous (2007). Report on the Species and Habitat Review. Joint Nature Conservation Committee, Peterborough.

Ardelean, C., Ardelean, A. \& Boceanu, B. (2018). New Epipactis (Orchidaceae) species for the Romanian flora. Res. J. Agric. Sci. 50: 3 - 15.

Barrett, S. C. H., Arunkumar, R. \& Wright, S. I. (2014). The demography and population genomics of evolutionary transitions to self-fertilization in plants. Philos. Trans. Roy. Soc. B 369 (1648).

Bateman, R. M. (1999). Integrating molecular and morphological evidence for evolutionary radiations. In: P. M. Hollingsworth, R. M. Bateman \& R. J. Gornall (eds), Molecular systematics and plant evolution, pp. 432 - 471. Taylor \& Francis, London.

(2001). Evolution and classification of European orchids: insights from molecular and morphological characters. J. Eur. Orchid. 33: 33 - 119.

(2006). How many orchid species are currently native to the British Isles? In: J. Bailey \& G. Ellis (eds), Current taxonomic research on the British $\mathcal{E}^{\circ}$ European flora, pp. 89 - 110. Botanical Society of the British Isles, London.

(2009). Evolutionary classification of European orchids: the crucial importance of maximising explicit evidence and minimising authoritarian speculation. J. Eur. Orchid. 41: 243 - 318.

(2012). Circumscribing species in the European orchid flora: multiple datasets interpreted in the context of speciation mechanisms. Ber. Arbeitskreis. Heimische Orchid. 8: 160 - 212.

(2016). Après le déluge: ubiquitous field barcoding should drive 21 st century taxonomy. In: 
P. D. Olson, J. Hughes \& J. A. Cotton (eds), Next generation systematics, pp. 123 - 153. Systematics Association Special Volume 85. Cambridge University Press, Cambridge.

(2018). Two bees or not two bees? An overview of Ophrys systematics. Ber. Arbeitskreis. Heimische Orchid. 35: 5 - 46 .

Hollingsworth, P. M., Squirrell, J. \& Hollingsworth, M. L. (2005). Tribe Neottieae: Phylogenetics. In: A. M. Pridgeon, P. J. Cribb, M. W. Chase \& F. N. Rasmussen (eds), Genera Orchidacearum 4. Epidendroideae 1, pp. 487 - 495. Oxford University Press, Oxford.

\& Rudall, P. J. (2006). The Good, the Bad and the Ugly: using naturally occurring terata to distinguish the possible from the impossible in orchid floral evolution. Aliso (Monocot Special Volume) 22: 481 496.

Sramkó, G. \& Paun, O. (2018). Integrating restriction site-associated DNA sequencing (RADseq) with morphological cladistic analysis clarifies evolutionary relationships among major species groups of bee orchids. Ann. Bot. 121: 85 - 105.

Bentham, G. \& Hooker, J. D. (1920). Handbook of the British flora, 6th edn. Reeve, London.

Besser, W. S. J. G. von. (1809). Primitiae florae Galiciae austriacae utriusque, 2. Doll, Vienna.

Bidartondo, M. I., Burghardt, B., Gebauer, G., Bruns, T. D. \& Read, D. J. (2004). Changing partners in the dark: isotopic and molecular evidence of ectomycorrhizal liaisons between forest orchids and trees. Proc. Roy. Soc. London, Ser. B, Biol. Sci. 271: 1799 - 1806.

Brandrud, M. K., Baar, J., Lorenzo, M. T., Athanasiadis, A., Bateman, R. M., Chase, M. W., Hedrén, M. \& Paun, O. (2019). Phylogenomic relationships of diploids and the origins of allotetraploids in Dactylorhiza (Orchidaceae): RADseq data track reticulate evolution. Syst. Biol. 69: 91 109. https://doi.org/10.1093/sysbio/syz035

Brys, R. \& Jacquemyn, H. (2016). Severe outbreeding and inbreeding depression maintain mating system differentiation in Epipactis (Orchidaceae). J. Evol. Biol. 29: 352 - 359.

Buttler, K. P. (1986). Epipactis helleborine subsp. neerlandica. In: W. Greuter \& T. Raus (eds), MedChecklist Notulae, 13. Willdenowia 16: 103 - 116.

Cheffings, C. M., Farrell, L., Dines, T. D., Jones, R. A., Leach, S. J., McKean, D. R., Pearman, D. A., Preston, C. D., Rumsey, F. J. \& Taylor. I. (2005). The vascular plant Red Data List for Great Britain (Species Status 7). Joint Nature Conservation Committee, Peterborough.

Claessens, J. \& Kleynen, J. (2011). The flower of the European orchid: form and function. Published by the authors, Voerendaal.
$\&$ (2016). Many ways to get happy: pollination modes of European Epipactis species. Orchid Digest 80: 142 - 150.

\& Wiellnga, R. (1998). Some notes on Epipactis helleborine (L.) Crantz ssp. neerlandica (Vermeulen) Buttler and Epipactis renzii $\mathrm{K}$. Robatsch. Eurorchis 10: 55 - 64.

Clapham, A. R. (1962). Epipactis. In: A. R. Clapham, T. G. Tutin \& E. F. Warburg, Flora of the British Isles (2nd edn): 1016 - 1021. Cambridge University Press, Cambridge.

, Tutin, T. G. \& Moore, D. M. (1987). Flora of the British Isles, 3rd edn. Cambridge University Press, Cambridge.

Clark, M. J. (2011). Studies on Epipactis helleborine s.l. at Kenfig NNR. J. Hardy Orchid Soc. 8 (1): $24-28$.

Curtis, T. G. F. \& Thompson, R. (2009). The orchids of Ireland. National Museums Northern Ireland: Holywood, Co. Down.

Delforge, P. (1995). Epipactis dunensis (T. \& T.A. Stephenson) Godfery et Epipactis muelleri Godfery dans les îles Britanniques. Naturalistes Belges 76: 103 - 123.

(2000). Nouvelles contributions taxonomiques et nomenclaturelles aux orchidées d'Europe. Naturalistes Belges 81: 396 - 398.

(2006). Orchids of Europe, North Africa and the Middle East. A \& C Black, London.

(2016). Orchidées d'Europe, d'Afrique du Nord et du Proche-Orient, 4th edn. Delachaux \& Niestlé, Paris.

\& Gévaudan, A. (2002). Contribution taxonomique et nomenclaturale au groupe d'Epipactis leptochila. Naturalistes Belges 83: 19 - 35.

Devillers-Terschuren, J. \& Devillers, P. (1991). Contributions taxonomiques et nomenclaturales aux Orchidées d'Europe (Orchidaceae). Naturalistes Belges 72: 100.

Efimov, P. (2004). Genus Epipactis Zinn. (Orchidaceae) in Russia [in Russian]. Turczaninowia 7(3): 8- 42.

Ehlers, B. K., Olesen, J. M. \& Agren, J. (2002). Floral morphology and reproductive success in the orchid Epipactis helleborine: regional and local across-habitat variation. Pl. Syst. Evol. 236: 19 - 32.

Ettlinger, D. M. T. (1997). Notes on British and Irish Orchids. Published by the author, Dorking.

(1998). Illustrations of British and Irish Orchids. Published by the author, Dorking.

Fateryga, A. V. \& Fateryga, V. V. (2018). The genus Epipactis Zinn (Orchidaceae) in the flora of Russia. Turczaninowia 21: 19 - 34 [In Russian].

, Popovich, A. V., Fateryga, V. V., Averyanova, E. A. \& Kreutz, C. A. J. (2018). New data on the genus Epipactis (Orchidaceae) in the North Caucasus with description of a new species. Phytotaxa 358: 278 288.

Gévaudan, A. (1999). Epipactis leptochila (Godfery) Godfery — variabilité des populations des Alpes et 
du Jura francais, considérations systematique et taxonomatiques. Naturalistes Belges 80: $343-375+2$ plates.

Godfery, M. J. (1919). Epipactis media (Fries) Bab. J. Bot. 57: $80-83$.

(1920). Epipactis viridiflora Reich. J. Bot. 58: 33 - 37 + pIate 553 .

(1921). Epipactis leptochila Godf. J. Bot. 59: 146 147.

(1926). Epipactis dunensis Godf. J. Bot. 64: 65 - 68 . (1933). Monograph and iconograph of native British Orchidaceae. Cambridge University Press, Cambridge.

Graham, J. H., Raz, S., Hel-Or, H. \& Nevo, E. (2010). Fluctuating asymmetry: methods, theory, and applications. Symmetry 2: $466-540$.

Harrap, A. \& Harrap, S. (2009). Orchids of Britain and Ireland, 2nd edn. A \& C Black, London.

Harrap, S. (2009). What is the British distribution of Epipactis leptochila (Narrow-lipped Helleborine)? BSBI News \#111: 12 - 14.

Harris, S. A. \& Abbott, R. J. (1997). Isozyme analysis of the reported origin of a new hybrid orchid species, Epipactis youngiana (Young's helleborine), in the British Isles. Heredity 79: 402 - 407.

Harrison, N. \& Kidner, C. A. (2011). Next-generation sequencing and systematics: what can a billion base pairs of DNA sequence data do for you? Taxon 60: 1552 - 1566.

Hoffmann, G. F. (1804). Deutschlands Flora, 3, ii. Palm, Erlangen.

Hollingsworth, P. M., Squirrell, J., Hollingsworth, M. L., Richards, A. J. \& Bateman, R. M. (2006). Taxonomic complexity, conservation and recurrent origins of self-pollination in Epipactis (Orchidaceae). In: J. Bailey \& R. G. Ellis (eds), Current taxonomic research on the British E European flora, pp. 27 - 44. Botanical Society of the British Isles, London.

Igic, B. \& Busch, J. W. (2013). Is self-fertilization an evolutionary dead end? New Phytol. 198: 386 - 397.

Jacquemyn, H., De Kort, H., Broeck, A. V. \& Brys, R. (2018). Immigrant and extrinsic hybrid seed inviability contribute to reproductive isolation between forest and dune ecotypes of Epipactis helleborine (Orchidaceae). Oikos 127: 73 - 84.

Waud, M., Lievens, B. \& Brys, R. (2016). Differences in mycorrhizal communities between Epipactis palustris, E. helleborine and its presumed sister species E. neerlandica. Ann. Bot. 118: 105 114.

Kapteyn den Boumeester, D. W. (1989). Epipactis helleborine var. neerlandica Vermeulen propblematiek, veldwaarmeningen, bestuivers. Eurorchis 1: 93 - 112. (2018a). Enige opmerkingen over Epipactis helleborine var. neerlandica Vermeulen (Duinwespenorchis). Liparis 24: 96 - 104.

(2018b). Orchideeënonderzoek. https:// www.dwkdb.nl/orch-onderz/kdbneerlandica.html.

Klingenberg, C. P. (2010). Evolution and development of shape: integrating quantitative approaches. Nat. Rev. Genetics 11: 623 - 635.

Kreutz, C. A. J. (2004). Catalogue of European orchids. Published by the author, Landgraaf.

(2005). Veldgids Nederlandse Orchideeёn. Published by the author, Landgraaf.

(2007). Epipactis dunensis (T. \& T.A. Stephenson) Godfery subsp. tynensis Kreutz, Eine neue Epipactissippe aus Nordengland und Südschottland. J. Eur. Orch. 39: 123 - 134.

Kropf, M. \& Renner, S. (2008). Pollinator-mediated selfing in two deceptive orchids and a review of pollinium tracking studies addressing geitonogamy. Oecologia 155: 497 - 508.

Kuiper, M., Oostermeijer, G. \& Gravendeel, B. (2009). Duinwespenorchis: standplaats - variatie of sort in wording? Orchideen 71: 82 - 86.

Lang, D. (2004). Britain's orchids. Wild Guides, Old Basing, Hampshire.

Lewis, L. (2003). Dune forms of Epipactis helleborine at Kenfig. Hardy Orchid Soc. Newsl. \#28: 15 - 17.

(2017). Green-flowered Helleborine, Epipactis phyllanthes in England and Wales. J. Eur. Orchid. 49: 153 - 165 .

Clark, M. J. \& Spencer, E. J. (2009). An update on the orchid flora at Kenfig National Nature Reserve. BSBI News \#110: 7 - $11+1$ plate.

\& Spencer, E. J. (2005). An update on the orchid flora at Kenfig National Nature Reserve. Watsonia 25: $290-295$.

Linnaeus, C. (1753). Species plantarum, 1st edn. Salvii, Stockholm.

Molnár, A. V. (ed) (2011). Magyarország Orchideáinak Atlasza. Kossuth Kiadó, Budapest.

Olson, P. D., Hughes, J. \& Cotton, J. A. (eds) (2016). Next generation systematics. Cambridge University Press, Cambridge.

Paun, O., Bateman, R. M., Fay, M. F., Hedrén, M., Civeyrel, L. \& Chase, M. W. (2010). Stable epigenetic effects impact evolution and adaptation in allopolyploid orchids. Molec. Biol. Evol. 27: 2465 2473.

Pedersen, H. A. E. \& Ehlers, B. K. (2000). Local evolution of obligate autogamy in Epipactis helleborine subsp. neerlandica (Orchidaceae). Pl. Syst. Evol. 223: 173 - 183 .

Proctor, M. C. F. \& Yeo, P. (1973). The pollination of flowers. Collins, London. 
, Yeo, P. \& Lack, A. (1996). The natural history of pollination. HarperCollins, London.

Richards, A. J. (1982). The influence of minor structural changes in the flower on breeding systems and speciation in Epipactis Zinn. (Orchidaceae). In: J. A. Armstrong, J. M. Powell \& A. J. Richards (eds), Pollination and evolution, pp. 47 - 53. Royal Botanical Gardens Sydney, Sydney. (1986a). Plant breeding systems. Chapman \& Hall, London.

(1986b). Cross-pollination by wasps in Epipactis leptochila (Godf.) Godf. s.l. Watsonia 16: 180 - 182. (2015). Epipactis. In: C. A. Stace, C. D. Preston \& D. A. Pearman (eds), Hybrid flora of the British Isles: 333 334. Botanical Society of Britain and Ireland, Bristol. \& Porter, A. F. (1982). On the identity of a Northumberland Epipactis. Watsonia 14: 121 - 128. \& Squirrell, J. (2009). Epipactis leptochila complex in Britain. BSBI News, \#112: 8 - 9.

\& Swan, G. A. (1976). Epipactis leptochila (Godf.) Godf. and E. phyllanthes G.E.Sm. occurring in South Northumberland on lead and zinc soils. Watsonia 11: $1-5$.

Robatsch, K. (1995). Beiträge zur Kenntnis des europäischen Epipactis-Arten (Orchidaceae) und zur Evolution der Autogamie bei europäischen und asiatischen Gattungen der Neottioideae. J. Eur. Orch. 27: 125 - 177.

Schiebold, J. M. I., Bidartondo, M. I., Karasch, P., Gravendeel, B. \& Gebauer, G. (2017). You are what you get from your fungi: nitrogen stable isotope patterns in Epipactis species. Ann. Bot. 119: 1085 - 1095.

Sell, P. D. \& Murrell, G. (1996). Flora of Great Britain and Ireland, 5: Butomaceae - Orchidaceae. Cambridge University Press, Cambridge.

Selosse, M. A., Faccio, A., Scappaticci, G. \& Bonfante, P. (2004). Chlorophyllous and achlorophyllous specimens of Epipactis microphylla (Neottieae, Orchidaceae) are associated with ectomycorrhizal septomycetes, including truffles. Microb. Ecol. 47: 416 - 427.

Smith, G. E. (1852). Epipactis phyllanthes. Gard. Chron., 16th October: 660.

Smith, J. E. (1828). The English Flora, 4. Longman, London. Squirrell, J., Hollingsworth, P. M., Bateman, R. M., Dickson, J. H., Light, M. H. S., McConaill, M. \& Tebbitt, M. C. (2001). Partitioning and diversity of nuclear and organelle markers in native and introduced populations of Epipactis helleborine (Orchidaceae). Amer. J. Bot. 88: 1409 - 1418.

Tebbitt, M. C. \& Hollingsworth, M. L. (2002). Taxonomic complexity and breeding system transitions: conservation genetics of the Epipactis leptochila complex (Orchidaceae). Molec. Ecol. 11: 1957 - 1964.

Sramkó, G., Paun, O., Brandrud, M. K., Laczko, L., Molnár, A. V. \& Bateman, R. M. (2019). Iterative allogamy-autogamy transitions drive actual and incipient speciation during the ongoing evolutionary radiation within the orchid genus Epipactis (Orchidaceae). Ann. Bot. 124: 481 - 497. https:// doi.org/10.1093/aob/mcz103.

Stace, C. A. (1991). New flora of the British Isles, 1st edn. Cambridge University Press, Cambridge.

(2010). New flora of the British Isles, 3rd edn. Cambridge University Press, Cambridge.

Stephenson, T. \& Stephenson, T. A. (1918). A new form of Helleborine viridiflora. J. Bot. 56: $1-4$. \& __ (1921). Epipactis viridiflora. J. Bot. 59: 205.

Stroh, P. A., Leach, S. J., August, T. A., Walker, K. J., Pearman, D. A., Rumsey, F. J., Harrower, C. A., Fay, M. F., Martin, J. P., Pankhurst, T., Preston, C. D. \& Taylor, I. (2014). A vascular plant Red List for England. Botanical Society of Britain and Ireland, Bristol.

Summerhayes, V. S. (1951). Wild orchids of Britain, 1st edn. Collins, London.

(1968). Wild orchids of Britain, 2nd edn. Collins, London.

Takebayashi, N. \& Morrell, P. L. (2001). Is selffertilization an evolutionary dead end? Revisiting an old hypothesis with genetic theories and a macroevolutionary approach. Amer. J. Bot. 88: 1143 - 1150. https://doi.org/10.2307/3558325.

Tałałaj, I. \& Brzosko, E. (2008). Selfing potential in Epipactis palustris, E. helleborine and E. atrorubens (Orchidaceae). Pl. Syst. Evol. 276: 21 - 29.

Templeton, A. R. (1989). The meaning of species and speciation: a genetic perspective. In: D. Otte \& J. A. Endler (eds), Speciation and its consequences, pp. 3 27. Sinauer, Sunderland, Massachusetts.

Thomas, C. (1950). The Kenfig Epipactis. Watsonia 1: $283-288$.

Tranchida-Lombardo, V., Cafasso, D., Cristaudo, A. \& Cozzolino, S. (2011). Phylogeographic patterns, genetic affinities and morphological differentiation between Epipactis helleborine and related lineages in a Mediterranean glacial refugium. Ann. Bot. 107: 427 - 436.

Tyteca, D. \& Dufrene, M. (1994). Biostatistical studies of western European allogamous populations of the Epipactis helleborine (L.) Crantz species group (Orchidaceae). Syst. Bot. 19: $424-442$.

Van den Bussche, W. (2004). Enkele aantekeningen betreffende de taxonomische status van Epipactis helleborine "neerlandica" (Orchidaceae). Eurorchis 16: $75-88$.

Vermeulen, P. (1949). Varieties and forms of Dutch orchids. Nederl. Kruidk. Arch. 56: $204-242$.

(1958). Orchidaceae. Flora Neerlandica 1: 100 105.

Wheldon, J. A. \& Travis, W. G. (1913). Helleborine viridiflora in Britain. J. Bot. 51: 343 - 346. 
Wiley, E. O. \& Mayden, R. L. (2000). The evolutionary species concept. In: Q. D. Wheeler \& R. Meier (eds), Species concepts and phylogenetic theory, pp. 70 89, 198 - 208. Columbia University Press, New York. Wright, S. I., Kalisz, S. \& Slotte, T. (2013). Evolutionary consequences of self-fertilization in plants. Proc. Roy. Soc. London, Ser. B, Biol. Sci. 280.

Young, D. P. (1948). Studies in the British Epipactis, 1. Epipactis dunensis and E. pendula. Watsonia 1: $102-112$. (1952a). Studies in the British Epipactis, 3. Epipactis phyllanthes G. E. Sm., an overlooked species. Watsonia 2: $253-259$.

(1952b). Studies in the British Epipactis, 4. A revision of the phyllanthes-vectensis-pendula group.
Watsonia 2: 259 - 276.

(1962a). Studies in the British Epipactis, 5. Epipactis leptochila; with some notes on E. dunensis and E. muelleri. Watsonia 5: 127 - 135.

(1962b). Studies in the British Epipactis, 6. Some further notes on E. phyllanthes. Watsonia 5: 136-139.

\section{Publisher's Note}

Springer Nature remains neutral with regard to jurisdictional claims in published maps and institutional affiliations. 